Review

\title{
Positron Emission Tomography in Animal Models of Alzheimer's Disease Amyloidosis: Translational Implications
}

\author{
Ruiqing $\mathrm{Ni}^{1,2}$ \\ 1 Institute for Biomedical Engineering, ETH \& University of Zurich, 8093 Zurich, Switzerland; \\ ni@biomed.ee.ethz.ch \\ 2 Institute for Regenerative Medicine, University of Zurich, 8952 Zurich, Switzerland
}

Citation: Ni, R. Positron Emission Tomography in Animal Models of Alzheimer's Disease Amyloidosis: Translational Implications. Pharmaceuticals 2021, 14, 1179 . https://doi.org/10.3390/ ph14111179

Academic Editor: Xuyi Yue

Received: 18 October 2021

Accepted: 15 November 2021

Published: 18 November 2021

Publisher's Note: MDPI stays neutral with regard to jurisdictional claims in published maps and institutional affiliations.

Copyright: (C) 2021 by the author. Licensee MDPI, Basel, Switzerland. This article is an open access article distributed under the terms and conditions of the Creative Commons Attribution (CC BY) license (https:/ / creativecommons.org/licenses/by/ $4.0 /)$.

\begin{abstract}
Animal models of Alzheimer's disease amyloidosis that recapitulate cerebral amyloid-beta pathology have been widely used in preclinical research and have greatly enabled the mechanistic understanding of Alzheimer's disease and the development of therapeutics. Comprehensive deep phenotyping of the pathophysiological and biochemical features in these animal models is essential. Recent advances in positron emission tomography have allowed the non-invasive visualization of the alterations in the brain of animal models and in patients with Alzheimer's disease. These tools have facilitated our understanding of disease mechanisms and provided longitudinal monitoring of treatment effects in animal models of Alzheimer's disease amyloidosis. In this review, we focus on recent positron emission tomography studies of cerebral amyloid-beta accumulation, hypoglucose metabolism, synaptic and neurotransmitter receptor deficits (cholinergic and glutamatergic system), blood-brain barrier impairment, and neuroinflammation (microgliosis and astrocytosis) in animal models of Alzheimer's disease amyloidosis. We further propose the emerging targets and tracers for reflecting the pathophysiological changes and discuss outstanding challenges in disease animal models and future outlook in the on-chip characterization of imaging biomarkers towards clinical translation.
\end{abstract}

Keywords: Alzheimer's disease; amyloid-beta; animal model; astrocyte; blood-brain barrier; imaging; metabolism; microglia; neuroinflammation; neurotransmitter receptors; positron emission tomography; synaptic density

\section{Introduction}

Alzheimer's disease (AD) is the most common cause of dementia, afflicting 50 million people worldwide [1]. AD is pathologically featured by amyloid-beta(A $\beta)$ plaques and neurofibrillary tangles formed by hyperphosphorylated tau, gliosis, neurotransmitter deficits, and neuronal loss leading to cognitive impairment [2]. The abnormal accumulation of $\mathrm{A} \beta$ deposits, especially the neurotoxic oligomeric $\mathrm{A} \beta$ plays a crucial role in the disease pathogenesis in animal models and in patients with AD [3-6]. Recent advances in positron emission tomography (PET) using $\left[{ }^{18} \mathrm{~F}\right]$ fluorodeoxyglucose (FDG), tracers for $\mathrm{A} \beta$ pathology and tauopathy, structural magnetic resonance imaging, and cerebrospinal fluid biomarkers have provided valuable insights into the time course of the pathophysiology of AD continuum, assisted the early and differential diagnosis, and facilitated the development of therapeutics for AD [7-11]. Disease animal models recapitulating AD amyloidosis have been developed including transgenic APP/PS1, APP23, APPswe, J20, PS2APP, arcA $\beta$, $5 \times$ FAD, $3 \times$ Tg mice, TgF344 and McGill-R-Thy1-APP rats [12-19], second-generation $\mathrm{App}^{\mathrm{NL}-\mathrm{G}-\mathrm{F}}, \mathrm{App}^{\mathrm{hu} / \mathrm{hu}}$ knock-in mice [20,21], third-generation mouse models [22,23], as well as non-human primate model [24]. The animal models accumulate cerebral A $\beta$ pathology, develop gliosis, metabolic and synaptic deficits, and cognitive impairment assessed by behavior tests, and facilitate the understanding of disease mechanisms and the development of treatment strategies. In this review, we focused on the recent development in PET imag- 
ing for $A \beta$, alterations in cerebral glucose metabolism, synaptic neurotransmitter receptors, blood-brain barrier, and neuroinflammation in rodent models of $\mathrm{AD}$ amyloidosis.

\section{Amyloid Imaging}

Ex vivo immunohistochemistry in brain tissues from amyloidosis mouse or rat models has revealed that $\mathrm{A} \beta$ pathology initiates first in the cortical region and spreads to the limbic region and finally to the cerebellum [25], in an animal line-dependent manner. A more pronounced load of $A \beta$ deposits was observed in $5 \times$ FAD mice, compared with that in APPswe mice [25-27]. In addition to the parenchymal A $\beta$ plaques, cerebral amyloid angiopathy (CAA) is also observed in different amyloidosis animal models, especially in the APPDutch mice, Tg-SwDI, APP/London, APP23, arcA $\beta$, and APPswe mice [28-30]. Several $A \beta$ imaging tracers have been developed and applied in animal models of amyloidosis, including benzothiazole derivatives $\left[{ }^{11} \mathrm{C}\right] \mathrm{PiB},\left[{ }^{18} \mathrm{~F}\right]$ flutemetamol, $\left[{ }^{18} \mathrm{~F}\right]$ florbetaben, $\left[{ }^{18} \mathrm{~F}\right] \mathrm{FIBT},\left[{ }^{18} \mathrm{~F}\right]$ florbetapir, $\left[{ }^{11} \mathrm{C}\right] \mathrm{AZD} 2184,\left[{ }^{18} \mathrm{~F}\right] \mathrm{FC} 119 \mathrm{~S}$ and $\left[{ }^{18} \mathrm{~F}\right]$ flutafuranol, benzofuran derivatives $\left[{ }^{18} \mathrm{~F}\right] \mathrm{FACS}$ and $\left[{ }^{18} \mathrm{~F}\right] \mathrm{FPZBF}-2$, benzoxazole derivatives $\left[{ }^{11} \mathrm{C}\right] \mathrm{BF}-227$ and $\left[{ }^{18} \mathrm{~F}\right] \mathrm{MK} 3328$, benzoselenazole derivative $\left[{ }^{18} \mathrm{~F}\right]$ fluselenamyl. hydroxyquinoline derivative $\left[{ }^{18} \mathrm{~F}\right] \mathrm{CABS} 13$, imidazopyridine derivative $\left[{ }^{18} \mathrm{~F}\right] \mathrm{DRKXH1}$, as well as $\left[{ }^{64} \mathrm{Cu}\right]$ labelled $8 \mathrm{a}^{\prime}-8 \mathrm{~d}$ and HYR-17 [31-47] (Table 1). Higher cortical amyloid PET tracer uptake was observed in various transgenic or knock-in animal models, compared with wild-type littermates, and validated by the ex vivo immunohistochemical stainings. Longitudinal comparative imaging studies across amyloidosis mouse lines have detected distinct $A \beta$ spreading patterns in vivo. Snellman et al. showed a greater $A \beta$ tracer dynamic range in the brain of the APP23 model, compared with that of APPswe and APP/PS1 models by PET imaging using both $\left[{ }^{11} \mathrm{C}\right] \mathrm{PiB}$ and $\left[{ }^{18} \mathrm{~F}\right]$ flutemetamol $[38,48]$. Brendel et al. compared four amyloidosis mouse strains (PS2APP, APPswe/PS1G384A, APP/PS1, APPswe) and found that PS2APP mice demonstrated greater dynamic changes in the longitudinal $\left[{ }^{18} \mathrm{~F}\right]$ florbetaben imaging study [49] (Figure 1a). Moreover, comparative studies of amyloid imaging tracers have been performed in a head-to-head manner in animal models, such as comparison among $\left[{ }^{11} \mathrm{C}\right] \mathrm{PiB},\left[{ }^{18} \mathrm{~F}\right]$ florbetaben, and $\left[{ }^{18} \mathrm{~F}\right] \mathrm{FIBT}[36]$, and between $\left[{ }^{18} \mathrm{~F}\right]$ florbetaben and $\left[{ }^{18} \mathrm{~F}\right]$ flutemetamol [50]; similar patterns of tracer detection of cerebral $\mathrm{A} \beta$ distribution in the animal models have been reported in general.

As the commonly used amyloid tracers cannot differentiate parenchymal $A \beta$ plaques and CAA [51], efforts have been made to develop CAA-specific tracers such as resorufin derivatives [52], $\left[{ }^{3} \mathrm{H}\right] 1,2$ [53]. One of the unsolved questions in $A \beta$ imaging is the detection of small forms of $A \beta$ aggregates. Biechele et al. recently indicated that the non-fibrillar $\mathrm{A} \beta$ (positive for 3552 antibodies) significantly impacted the $\left[{ }^{18} \mathrm{~F}\right]$ florbetaben PET signal, in addition to the Thiazine red-stained fibrillar A $\beta$, in App ${ }^{\mathrm{NL}-\mathrm{G}-\mathrm{F}}$ and APP/PS1 mice from 3-12 months of age [54]. In addition to the small chemical dyes, PET using A $\beta$ antibodies conjugated to a transferrin receptor antibody such as [ $\left.{ }^{124} \mathrm{I}\right] \mathrm{RmAb} 158-\mathrm{scFv} 8 \mathrm{D} 3$ and $\left[{ }^{124} \mathrm{I}\right] 8 \mathrm{D} 3-$ $\mathrm{F}\left(\mathrm{ab}^{\prime}\right) 2$-h158 have been developed to detect cerebral accumulation of small forms of $A \beta$. These tracers harbor an improved blood-brain barrier permeability and have been demonstrated in several transgenic mouse models of amyloidosis. Meier et al. demonstrated that the uptake of $\left[{ }^{124} \mathrm{I}\right] \mathrm{RmAb} 158-\mathrm{scFv} 8 \mathrm{D} 3$ and $\left.\left[{ }^{124} \mathrm{I}\right] 8 \mathrm{D} 3-\mathrm{F}(\mathrm{ab})^{\prime}\right) 2-\mathrm{h} 158$ was significantly higher in the cortical regions of transgenic ArcSwe mice, compared with non-transgenic littermates. In addition, the distribution pattern of PET using [124 I]8D3-F( $\left.\mathrm{ab}^{\prime}\right) 2$-h158 differs from that by PET using $\left[{ }^{11} \mathrm{C}\right] \mathrm{PiB}$ in the brain of tg-ArcSwe mice, indicating a preference to different types of $A \beta$ by these two tracers (Figure $1 b-d$ ) [55]. Given the quantitativeness of in vivo microPET, non-invasive imaging using $\left[{ }^{18} \mathrm{~F}\right]$ florbetaben and $\left[{ }^{18} \mathrm{~F}\right]$ florbetapir for $A \beta$ load have been applied for longitudinal monitoring of the treatment effect in animal models, such as using $\gamma$-secretase modulator and $\beta$-secretase 1 inhibitor [56-58]. Xu et al. recently demonstrated using $\left[{ }^{11} \mathrm{C}\right] \mathrm{SGSM}-1560$ for in vivo detection of an increased level of $\gamma$-secretase in $5 \times \mathrm{FAD}$, compared with wild-type mice [59] (Figure 1e-g). 

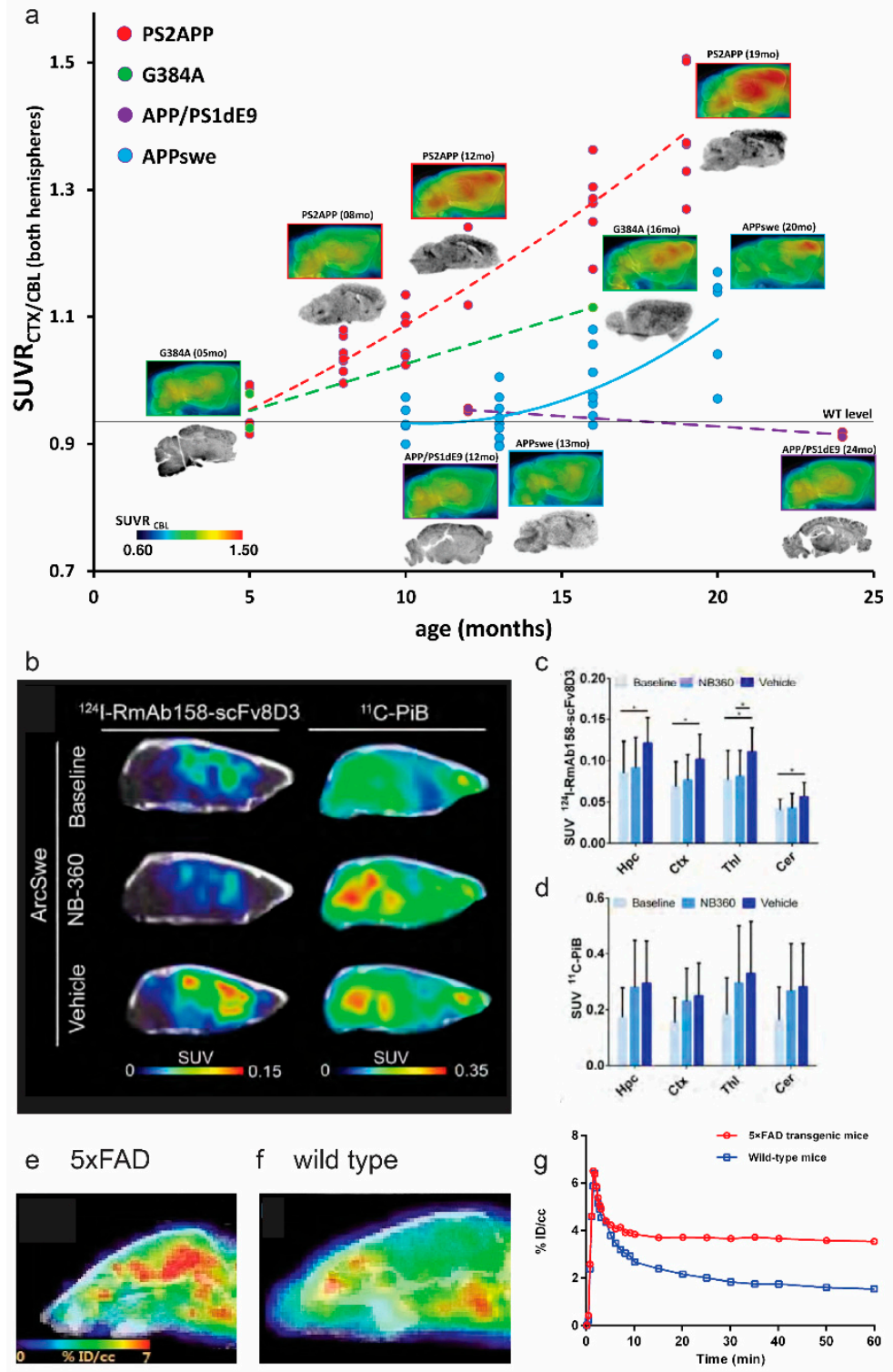

Figure 1. Imaging of amyloid-beta accumulation, and gamma-secretase in amyloidosis animal models of Alzheimer's disease: (a) multi-modal analysis of the four AD mouse strains in crosssectional $\left[{ }^{18} \mathrm{~F}\right]$ florbetaben PET study. Images indicate group averaged sagittal PET slices, normalized to the cerebellum as well as ex vivo autoradiography. Dots indicate PET SUVR cortex/cerebellum in individual mice. Dashed lines express the estimated time-dependent progression in PS2APP, APPswe/PS1G384A, and APP/PS1 mice, fitted with a polynomial function. Reproduced from [49] with permission from PLOS One; $(\mathbf{b}-\mathbf{d})$ PET images and quantification of $\left[{ }^{11} \mathrm{C}\right] \mathrm{PiB}(40-60 \mathrm{~min}$ after injection) and [ $\left.{ }^{124} \mathrm{I}\right] \mathrm{RmAb} 158$-scFv8D3 scans (72 $\mathrm{h}$ after injection) expressed as standardized uptake value (SUV): (b) comparison of representative $\left[{ }^{124} \mathrm{I}\right] \mathrm{RmAb} 158-\mathrm{scFv} 8 \mathrm{D} 3$ and $\left[{ }^{11} \mathrm{C}\right] \mathrm{PiB}$ PET images in ArcSwe animals; (c,d) quantification of $\left[{ }^{124} \mathrm{I}\right] \mathrm{RmAb} 158-\mathrm{scF} v 8 \mathrm{D} 3$ and $\left[{ }^{11} \mathrm{C}\right] \mathrm{PiB}$ in hippocampus (Hpc), cortex (Ctx), thalamus (Thl) and cerebellum (Cer). ${ }^{*} p<0.05$. Reproduced from [55] with permission from the Society of Nuclear Medicine and Molecular Imaging; (e-g) PET-CT imaging of $\gamma$-secretase in $5 \times$ FAD and wild-type mice; (e) PET-CT image of $5 \times$ FAD mice $(n=2)$ and (f) wild-type mice $(n=2)$ after i.v. injection of $\left[{ }^{11} \mathrm{C}\right] S G S M-15606 ;(g)$ time activity curve of wholebrain uptake of $\left[{ }^{11} \mathrm{C}\right]$ SGSM-15606 in $\mathrm{h}$ and i. Data are expressed as the percentage of injected dose per cubic centimeter (\% ID/cc). Reproduced from [59] with permission from Rockefellfigureer University Press. 
Table 1. Amyloid-beta PET imaging in animal models of Alzheimer's disease amyloidosis.

\begin{tabular}{|c|c|c|}
\hline Tracer & Animal Model & References \\
\hline \multirow{6}{*}[{}^{11}\mathrm{C}]{$\mathrm{PiB}$} & APPswe mice & {$[37,48,60]$} \\
\hline & $5 \times$ FAD mice & [61] \\
\hline & APP/PS1 mice & {$[36,48,62-66]$} \\
\hline & $3 \times$ Tg mice & [67] \\
\hline & APP23 mice & {$[33,48,68]$} \\
\hline & Aged non-human primates & {$[69,70]$} \\
\hline \multirow{6}{*}[{}^{18}\mathrm{F}]{ florbetapir, AV-45 } & $5 \times$ FAD mice & {$[61,71]$} \\
\hline & TASTPM mice & [72] \\
\hline & APP/PS1 mice & {$[58,73]$} \\
\hline & PS2APP mice & {$[49,74]$} \\
\hline & APPswe mice & {$[49,75]$} \\
\hline & $\mathrm{App}^{\mathrm{NL}-\mathrm{G}-\mathrm{F}}$ mice & {$[54,74,76-78]$} \\
\hline \multirow[t]{4}{*}[{}^{18}\mathrm{F}]{ florbetaben, $\mathrm{AV}-1$} & APPswe/PS1G384A mice & [49] \\
\hline & APP-SL70 mice & {$[74,79]$} \\
\hline & TgF334 rats & [80] \\
\hline & $\mathrm{APP} / \mathrm{PS} 1$ mice & {$[49,54,66,81]$} \\
\hline \multirow{2}{*}[{}^{11}\mathrm{C}]{$\mathrm{AZD} 2184$} & APPswe mice & [82] \\
\hline & APP/PS1 mice & [83] \\
\hline \multirow{2}{*}{$\begin{array}{c}{\left[{ }^{18} \mathrm{~F}\right] \text { flutafuranol AZD4694, }} \\
\text { NAV4694 }\end{array}$} & McGill-R-Thy1-APP rats & [43] \\
\hline & APPswe mice & [42] \\
\hline$\left[{ }^{18} \mathrm{~F}\right]$ flutemetamol & $\begin{array}{l}\text { APP23, APPswe, APP/PS1 } \\
\text { mice }\end{array}$ & {$[37,38]$} \\
\hline$\left[{ }^{18} \mathrm{~F}\right] \mathrm{FIBT}$ & $\mathrm{APP} / \mathrm{PS} 1$ mice & [36] \\
\hline$\left[{ }^{18} \mathrm{~F}\right] \mathrm{FC} 119 \mathrm{~S}$ & $5 \times$ FAD, $\mathrm{APP} / \mathrm{PS} 1$ mice & {$[34,35]$} \\
\hline$\left[{ }^{18} \mathrm{~F}\right] \mathrm{FACT},\left[{ }^{11} \mathrm{C}\right] \mathrm{BF}-227$ & APP/PS1 mice & {$[84,85]$} \\
\hline$\left[{ }^{18} \mathrm{~F}\right]$ fluselenamyl & $\mathrm{APP} / \mathrm{PS} 1$ mice & [86] \\
\hline$\left[{ }^{124} \mathrm{I}\right] \mathrm{RmAb} 158-\mathrm{scFv} 8 \mathrm{D} 3$ & Tg-ArcSwe, App ${ }^{\text {NL-G-F }}$ mice & [55] \\
\hline$\left[{ }^{124} \mathrm{I}\right] 8 \mathrm{D} 3-\mathrm{F}\left(\mathrm{ab}^{\prime}\right) 2-\mathrm{h} 158$ & Tg-ArcSwe, APPswe mice & [87] \\
\hline$\left[{ }^{18} \mathrm{~F}\right] \mathrm{CDA}-3$ & $5 \times$ FAD mice & [88] \\
\hline$\left[{ }^{64} \mathrm{Cu}\right] \mathrm{HYR}-17$ & $5 \times$ FAD mice & [39] \\
\hline$\left[{ }^{64} \mathrm{Cu}\right] 8 \mathrm{a}^{\prime}-8 \mathrm{~d}$ & $5 \times$ FAD mice & [44] \\
\hline$\left[{ }^{18} \mathrm{~F}\right] \mathrm{DRKXH} 1$ & APP/PS1 mice & [40] \\
\hline$\left[{ }^{18} \mathrm{~F}\right] \mathrm{CABS} 13$ & APP/PS1 mice & [41] \\
\hline
\end{tabular}

[11 C]AZD2184, 2-(6-[11C]methylaminopyridin-3-yl)-1,3-benzothiazol-6-ol; $\quad\left[{ }^{11} \mathrm{C}\right] \mathrm{BF}-227, \quad\left[{ }^{11} \mathrm{C}\right] 2-(2-[2-$ Dimethylaminothiazol-5-yl]ethenyl)-6-(2-[fluoro]ethoxy)benzoxazole; $\left[{ }^{18} \mathrm{~F}\right] \mathrm{CABS} 13,2-\left[{ }^{18} \mathrm{~F}\right]$ fluoroquinolin-8-ol; $\left[{ }^{18} \mathrm{~F}\right] \mathrm{CDA}-3,\left[{ }^{18} \mathrm{~F}\right]$ croconium dye for amyloid; $\left[{ }^{18} \mathrm{~F}\right] \mathrm{DRKXH1}, 5-\left(4-\left(6-\left(2-\left[{ }^{18} \mathrm{~F}\right]\right.\right.\right.$ fluoroethoxy)ethoxy)imidazo $[1,2-$ alpha]pyridin-2-yl)phenyl; Fab, antigen-binding fragment; [ $\left.{ }^{18} \mathrm{~F}\right] \mathrm{FACT}, 2-[(2-\{(\mathrm{E})-2-[2-($ dimethylamino)-1,3thiazol-5-yl]vinyl\}-1,3-benzoxazol-6-yl)oxy]-3-[ $\left.{ }^{18} \mathrm{~F}\right]$ fluoropropan-1-ol; $\quad\left[{ }^{18} \mathrm{~F}\right] \mathrm{FIBT}, \quad 2$-(p-methylaminophenyl)7-(2-[ $\left[{ }^{18} \mathrm{~F}\right]$ fluoroethoxy)imidazo-[2,1-b]benzothiazole; $\quad\left[{ }^{18} \mathrm{~F}\right] \mathrm{FC} 119 \mathrm{~S}, \quad 2-[2-(\mathrm{N}-$ monomethyl)aminopyridine6-yl]-6-[(S)-3- $\left[{ }^{18} \mathrm{~F}\right]$ fluoro-2-hydroxypropoxy]benzothiazole; $\quad\left[{ }^{18} \mathrm{~F}\right]$ florbetaben, $\quad 4-[(\mathrm{E})-2-[4-[2-[2-(2-$ $\left[{ }^{18} \mathrm{~F}\right]$ fluoranylethoxy)ethoxy]ethoxy]phenyl]ethenyl]-N-methylaniline; $\quad\left[{ }^{18} \mathrm{~F}\right]$ florbetapir, $\quad 4-[(\mathrm{E})-2-[6-[2-[2-$ (2-[ $\left.{ }^{18} \mathrm{~F}\right]$ fluoranylethoxy)ethoxy]ethoxy]pyridin-3-yl]ethenyl]-Nmethylaniline; $\left[{ }^{18} \mathrm{~F}\right]$ fluselenamyl, (Z)-5-(2-(5$\left(2-\left[{ }^{18} \mathrm{~F}\right]\right.$ fluoroethoxy)benzo[d][1,3]selenazol-2-yl)vinyl)-N,N-dimethylpyrimidin-2-amine; $\quad\left[{ }^{18} \mathrm{~F}\right]$ flutafuranol, 2-[2-[ $\left[{ }^{18} \mathrm{~F}\right]$ fluoro-6-(methylamino)-3-pyridinyl]-1-benzofuran-5-ol; $\quad\left[{ }^{18} \mathrm{~F}\right]$ flutemetamol, $\quad 2-\left[3-\left[{ }^{18} \mathrm{~F}\right]\right.$ fluoro-4(methylamino)phenyl]-1,3-benzothiazol-6-ol; $\left[{ }^{11} \mathrm{C}\right] \mathrm{PiB}$, Pittsburgh compound B, 2-[4-([11 C]methylamino)phenyl]1,3-benzothiazol-6-ol; scFv, single chain fragment variable.

\section{Cerebral Glucose Metabolism Imaging}

Brain glucose dysregulation plays an important role in AD [89]. Post-mortem studies reported higher levels of brain tissue glucose concentration, lower levels of glucose transporter 3, and glycolytic flux in the brain from patients with $\mathrm{AD}$, compared with controls, associating with the severity of AD pathology [89]. $\left[{ }^{18} \mathrm{~F}\right]$ FDG PETs have been routinely used for detecting the reduced cerebral glucose metabolism (CMRglc) in disease-specific brain regions in patients with AD, Frontotemporal dementia, and Parkinson's disease to improve the diagnostic accuracy $[9,90]$. In lab settings, $\left[{ }^{18} \mathrm{~F}\right]$ FDG PET have been assessed along with $\mathrm{A} \beta$ imaging in various amyloidosis rodent models such as APPswe mice, $5 \times \mathrm{FAD}$, APP/PS1, $3 \times$ Tg, Tg4-42, TASTPM mice, and McGill-R-Thy1-APP rats [43,66,71,91-95] (Table 2) (Figure 2a). However, $\left[{ }^{18} \mathrm{~F}\right] \mathrm{FDG}$ uptake is known to be highly sensitive to experi- 
mental conditions such as anesthesia and handling, as well as genotype, age, and gender of the animal models [96]. Most of the studies in rodent amyloidosis models reported a global reduction in CMRglc, although few exceptions of increased CMRglc (associating with gliosis) were also reported [61]. A recent study by Xiang et al. further showed that microglial activation states drive glucose uptake and $\left[{ }^{18}\right.$ F]FDG-PET alterations [97].

Table 2. PET imaging in of neurotransmitter receptors, blood-brain barriers, enzymes, metabolism, and synaptic density in animal models of Alzheimer's disease amyloidosis.

\begin{tabular}{|c|c|c|c|}
\hline Target & Tracer & Animal Model & References \\
\hline \multirow{10}{*}{ CMRglc } & \multirow{10}{*}[{}^{18}\mathrm{F}]{$\mathrm{FDG}$} & $3 \times$ Tg mice & [94,98-102], \\
\hline & & APPswe mice & [92] \\
\hline & & $\mathrm{APP} / \mathrm{PS} 1$ mice & {$[58,66,72,103-106]$} \\
\hline & & Tg4-42 mice & {$[91,107]$} \\
\hline & & $5 \times$ FAD mice & {$[61,71,81,108,109]$} \\
\hline & & $3 \times \mathrm{Tg}$ rats & [110] \\
\hline & & APP23 mice & [111] \\
\hline & & $\begin{array}{c}\text { McGill-R-Thy1-APP } \\
\text { rats }\end{array}$ & {$[43]$} \\
\hline & & TASTPM mice & {$[72,112]$} \\
\hline & & Aged monkey & [70] \\
\hline \multirow{3}{*}{ SV2A } & \multirow{2}{*}[{}^{11}\mathrm{C}]{$\mathrm{UCB}-\mathrm{J}$} & APP/PS1 mice & [113] \\
\hline & & ArcSwe, Tg-L61 mice & [114] \\
\hline & {$\left[{ }^{18} \mathrm{~F}\right]$ SynVesT-1 } & APP/PS1 mice & [115] \\
\hline \multirow{3}{*}{ mGluR5 } & & $5 \times$ FAD mice & {$[116,117]$} \\
\hline & {$\left[{ }^{18} \mathrm{~F}\right] \mathrm{FPEB}$} & APP/PS1 mice & [118] \\
\hline & {$\left[{ }^{11} \mathrm{C}\right] \mathrm{ABP} 688$} & Tg-ArcSwe mice & [119] \\
\hline \multirow{2}{*}{$\alpha 7 \mathrm{nAChR}$} & {$\left[{ }^{11} \mathrm{C}\right] \mathrm{MeQAA}$} & Aged monkey & [69] \\
\hline & {$\left[{ }^{18} \mathrm{~F}\right] \mathrm{ASEM}$} & TgF334 rats & {$[80]$} \\
\hline AChE & {$\left[{ }^{11} \mathrm{C}\right] \mathrm{MP} 4 \mathrm{~A}$} & APP23 mice & [120] \\
\hline BChE & {$\left[{ }^{11} \mathrm{C}\right] 4$} & $5 \times$ FAD mice & [121] \\
\hline GABAR & {$\left[{ }^{11} \mathrm{C}\right]$ flumazenil } & APP23 mice & [120] \\
\hline GSM & {$\left[{ }^{11} \mathrm{C}\right]$ SGSM-1560 } & $5 \times$ FAD mice & [59] \\
\hline IIa HDAC & {$\left[{ }^{18} \mathrm{~F}\right]$ TFAHA } & $3 \times$ Tg mice & [122] \\
\hline GLP-1R & $\begin{array}{c}{ }^{[18} \text { F]FBEM-Cys }{ }^{39} \text { - } \\
\text { exendin- } 4\end{array}$ & $3 \times$ Tg mice & [102] \\
\hline $\mathrm{D}_{2} \mathrm{R}$ & {$\left[{ }^{18} \mathrm{~F}\right]$ fallypride } & $3 \times \mathrm{Tg}, 5 \times$ FAD mice & {$[102,117]$} \\
\hline MC1 & {$\left[{ }^{18} \mathrm{~F}\right] \mathrm{BCPP}-\mathrm{EF}$} & $\begin{array}{l}\text { Aged monkey, } \\
\text { SAMP10 mice }\end{array}$ & {$[69,70,123,124]$} \\
\hline \multirow{2}{*}{$\begin{array}{l}\text { Copper } \\
\text { MT }\end{array}$} & {$\left[{ }^{64} \mathrm{Cu}\right] \mathrm{GTSM}$} & TASTPM mice & [125] \\
\hline & {$\left[{ }^{11} \mathrm{C}\right] \mathrm{MPC}-6827$} & J20 mice & [126] \\
\hline \multirow[t]{2}{*}{ GSK3 $\beta$} & $\begin{array}{c}{\left[{ }^{11} \mathrm{C}\right] \mathrm{OCM}-44} \\
{\left[{ }^{3} \mathrm{H}\right] \mathrm{PF}-367}\end{array}$ & APPswe mice & [127] \\
\hline & {$\left[{ }^{11} \mathrm{C}\right] 2$} & $3 \times$ Tg mice & [128] \\
\hline RAGE & {$\left[{ }^{11} \mathrm{C}\right] \mathrm{FPS}-\mathrm{ZM} 1$} & APPswe mice & [129] \\
\hline ABCC1 & {$\left[{ }^{11} \mathrm{C}\right] \mathrm{BMP}$} & $\mathrm{APP} / \mathrm{PS} 1$ mice & [130] \\
\hline \multirow[t]{2}{*}{ ABCG2 } & {$\left[{ }^{11}\right.$ C]erlotinib } & $\mathrm{APP} / \mathrm{PS} 1$ mice & [131] \\
\hline & {$\left[{ }^{11} \mathrm{C}\right]$ tariquidar } & APP/PS1 mice & [131] \\
\hline \multirow[t]{2}{*}{ P-GP ABCB1 } & {$\left[{ }^{11} \mathrm{C}\right]$ metoclopramide } & APP/PS1 mice & [132] \\
\hline & (R)-[ $\left[{ }^{11} \mathrm{C}\right]$ verapamil & $\mathrm{APP} / \mathrm{PS} 1$ mice & [133] \\
\hline
\end{tabular}

ABC: ATP-binding cassette transporter; $\alpha 7 \mathrm{nAChR:} \alpha 7$ icotinic acetylcholine receptor; AChE, acetylcholine esterase; $\mathrm{BChE}$ : butyrylcholinesterase; CMRglc: cerebral metabolic rate of glucose; D2: dopamine receptor D2; $\left[{ }^{18} \mathrm{~F}\right] \mathrm{FDG}:\left[{ }^{18} \mathrm{~F}\right]$ fluorodeoxyglucose; GABAR: gamma-aminobutyric acid receptor; GLP-1R: glucagon-like peptide-1 receptor; GSK3 $\beta$ : glycogen synthase kinase-3b; GSM: $\gamma$-secretase modulator; IIa HDAC: class IIa histone deacetylases; LPS: lipopolysaccharide; MC1: mitochondrial complex 1; mGluR5: metabotropic glutamate receptor type 5; MT: microtubule; NP: nanoparticle; P-GP: P-glycoprotein; SV2A: synaptic vesicle glycoprotein 2A. 

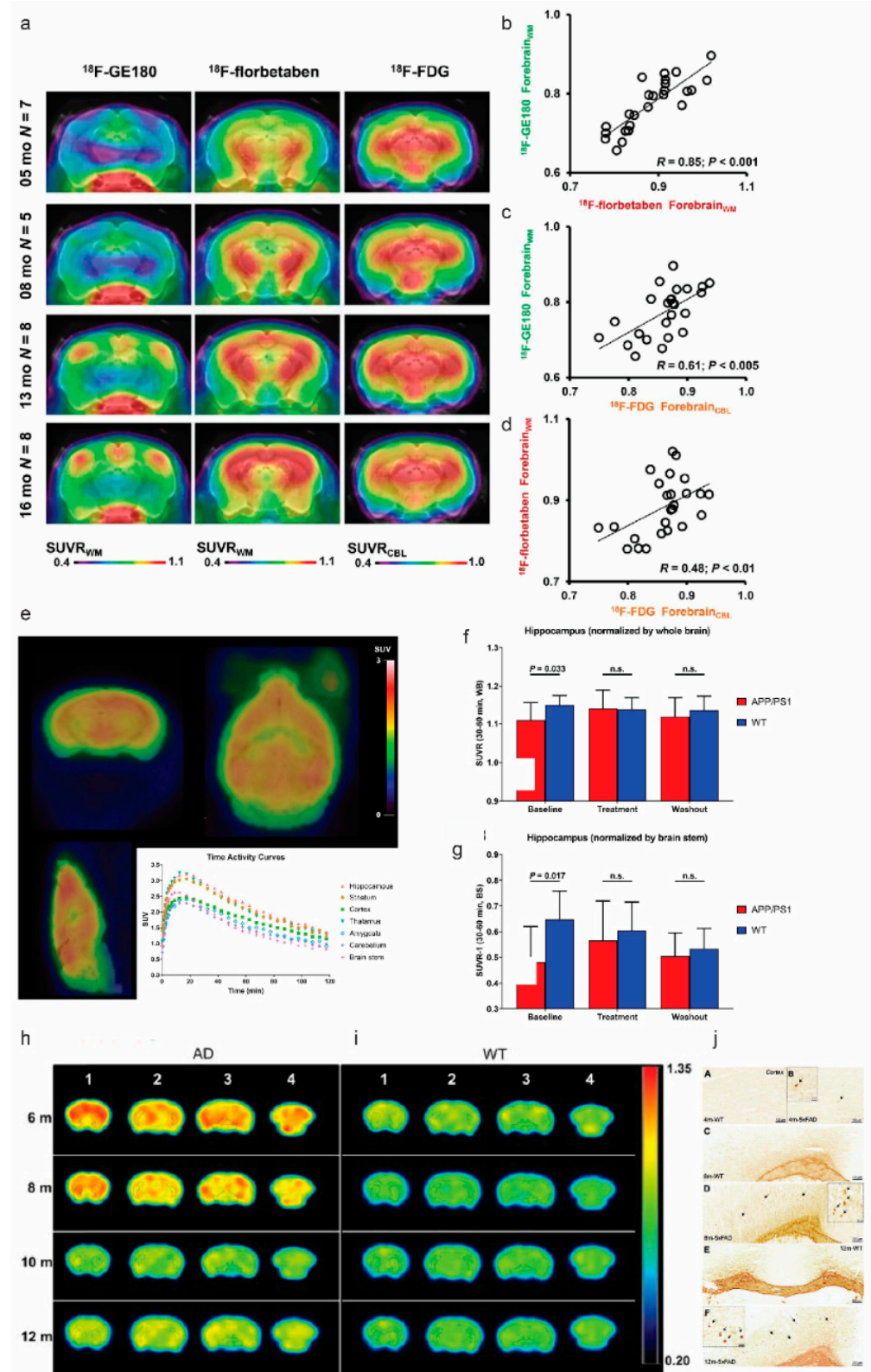

Figure 2. In vivo imaging of translocator protein, cerebral glucose metabolism, synaptic density, and butyrylcholinesterase, in amyloidosis animal models of Alzheimer's disease: (a-d) $\left[{ }^{18}\right.$ F]GE-180, $\left[{ }^{18} \mathrm{~F}\right]$ florbetaben, and $\left[{ }^{18} \mathrm{~F}\right]$ FDG PET imaging at different ages of PS2APP animals; (a) coronal planes of mean SUVR maps projected on an MRI mouse atlas (grayscale); (b-d) correlations between the different forebrain radiotracer SUVR for all PS2APP mice. Reproduced with permission [134] with permission from the Society of Nuclear Medicine and Molecular Imaging; $(\mathbf{e}-\mathbf{g})$ representative [ $\left.{ }^{11} \mathrm{C}\right] \mathrm{UCB}-\mathrm{J}$ PET image and time-activity curve in APP/PS1 mice; (a) static SUV image (30-60 min after injection) overlaid on atlas brain MR image; $(\mathbf{b}, \mathbf{c})$ hippocampal SUVRs in wild-type and APP/PS1 mice during baseline, treatment, and washout phases: whole-brain SUVR (b) and brain stem SUVR (c). Reproduced from [113] with permission Society of Nuclear Medicine; (h-j) PET images for BChE imaging in $5 \times$ FAD mice; (c,d) axial view of PET images in $5 \times$ FAD and wild-type mice after i.v. administration of $\left[{ }^{11} \mathrm{C}\right] 4$ at different ages; (e) Staining for BChE enzymatic activity in 4-, 8-, and 12-month-old brains of wild-type $(\mathbf{A}, \mathbf{C}, \mathbf{E})$ and $5 \times$ FAD mice $(\mathbf{B}, \mathbf{D}, \mathbf{F})$ using the Karnovsky-Roots method. BChE staining showed an increase in enzyme activity in the cerebral cortex of $5 \times$ FAD at different ages in comparison with wild-type ( $\mathbf{A}$ to $\mathbf{F}$ ) mice. Magnified images show the co-occurrence of plaques with BChE enzyme activity in different regions of the cerebral cortex $(\mathbf{B}, \mathbf{D}, \mathbf{F})$ Reproduced from [121] with permission from Ivyspring International Publisher. 


\section{Synaptic and Neurotransmitter Receptor Deficits}

\subsection{Synaptic Vesicle Glycoprotein $2 A$}

Synapse loss is reported in the post-mortem frontal cortex of patients with $\mathrm{AD}$, correlating with cognitive severity [135]. Synaptic vesicle glycoprotein 2A (SV2A) is located at the synapses across the entire brain and is the binding site for the antiepileptic drug levetiracetam [136]. SV2A involves in vesicle trafficking exocytosis and is crucial for neurotransmission and postnatal brain development [137]. Mendoza-Torreblanca et al. suggested that SV2A either regulates the presynaptic $\mathrm{Ca}^{2+}$ levels during repetitive activity or is a target for residual $\mathrm{Ca}^{2+}$. Higher loads of cerebral $\mathrm{A} \beta$ deposits have been reported in the brain of SV2A knock-out mice, compared with control littermates [138]. A 40\% reduction in SV2A signal by PET using [ $\left.{ }^{11} \mathrm{C}\right] \mathrm{UCB}-\mathrm{J}$ was observed in the hippocampus in patients with $\mathrm{AD}$, compared with cognitively normal control cases $[139,140]$. Kong et al. showed that SV2A over-expression was associated with the downregulation of $\beta$-site APP-cleaving enzyme 1 and apolipoprotein E genes, indicating that SV2A impacts A $\beta$ production. However, Nowack et al. showed that overexpression of SV2A increased synaptic levels of the calcium-sensor protein synaptotagmin, resulting in a neurotransmission deficit [141]. Thus, modulation of SV2A as a potential treatment requires careful dosing and close monitoring of the SV2A levels. Several SV2A PET imaging tracers have been developed including $\left[{ }^{11} \mathrm{C}\right]$ UCB-J, $\left[{ }^{18} \mathrm{~F}\right] \mathrm{UCB}-\mathrm{H}$ [142], $\left[{ }^{18} \mathrm{~F}\right]$ SynVesT-1 [143], $\left[{ }^{18} \mathrm{~F}\right] \mathrm{SDM}-8$ [144], and $\left.{ }^{18}{ }^{18} \mathrm{~F}\right] \mathrm{MNI}-1126$ [145] (Table 2). PET measures of $\mathrm{A} \beta$ deposition were found associated with regional synaptic density measured by $\left[{ }^{11} \mathrm{C}\right]$ UCB-J in patients with early AD [139,146]. Few studies have reported on SV2A imaging in AD animal models. Bertoglio et al. demonstrated that $\left[{ }^{11} \mathrm{C}\right]$ UCB-J is bound specifically to SV2A in mouse brain and that the radioligand binding can be quantified by kinetic modeling using an image-derived input function [147]. Toyonaga et al. showed that in vivo [ $\left.{ }^{11} \mathrm{C}\right] \mathrm{UCB}-\mathrm{J}$ detected reduced levels of SV2A in APP/PS1 mice and the treatment effects of tyrosine kinase Fyn inhibitor Saracatinib in mitigating the $\left[{ }^{11} \mathrm{C}\right] \mathrm{UCB}-\mathrm{J}$ reduction [113] (Figure 2e-g). Xiong et al. recently compared the $\left[{ }^{11} \mathrm{C}\right] \mathrm{UCB}-J$ binding in tg-ArcSwe and wild-type mice [114] and did not observe a clear difference between the two groups. $\left[{ }^{18} \mathrm{~F}\right] \mathrm{SynV}$ VesT-1, $\left[{ }^{18} \mathrm{~F}\right]$ analog of $\left[{ }^{11} \mathrm{C}\right] \mathrm{UCB}-\mathrm{J}$, has demonstrated favorable in vivo brain uptake in non-human primate [148]. Sadasivam et al. showed a lower $\left[{ }^{18} \mathrm{~F}\right]$ SynVesT-1 standard uptake value (SUV) across the whole brain of APP/PS1 mice, compared with non-transgenic mice [115]. The results from a static (30-60 min post-injection) $\left[{ }^{18} \mathrm{~F}\right]$ SynVesT-1 PET scan were found comparable to kinetic modeling results [115].

\subsection{Glutamate Receptors}

The glutamate receptors are classified into the N-methyl-D-aspartate receptor (NMDAR), $\alpha$-amino-3-hydroxy-5-methyl-4-isoxazolepropionate (AMPA)-kainate receptor, and metabotropic glutamate receptors (mGluRs). The glutamate receptors mediate excitatory neurotransmission, involve in multiple second messenger systems, and are essential in learning and memory $[149,150]$. Glutamate excitotoxicity and disruption of the glutamate receptor-mediated normal signaling are implicated in $\mathrm{AD}[151,152]$. A $\beta$ reduces glutamatergic transmission and inhibits synaptic plasticity $[153,154]$. Direct interaction between A $\beta$ oligomers and glutamate receptors including NMDAR [155], mGluR subunit mGluR5 [156], AMPA receptor subunit GluA3 [157], and GluA1 [158] have been demonstrated, leading to impaired synaptic plasticity in the animal models [159]. Chronic pharmacological inhibition of mGluR5 has been shown to prevent cognitive impairment and reduce pathological development in APP/PS1 mice [160]. Thus, glutamate receptors have been important targets for $\mathrm{AD}$ therapeutics. Several imaging tracers for glutamate receptors have been developed, including $\left[{ }^{11} \mathrm{C}\right] \mathrm{K}-2$ [161] and $\left[{ }^{11} \mathrm{C}\right] \mathrm{HMSO11}$ [162] for AMPA receptor, $\left[{ }^{18} \mathrm{~F}\right] \mathrm{GE}-179$ [163] and $\left[{ }^{18} \mathrm{~F}\right] \mathrm{PK}-209$ for NMDAR [164], $\left.{ }^{11} \mathrm{C}\right] \mathrm{Me}-\mathrm{NB} 1$ [165] for NMDAR GluN1/GluN2B subunits [166], as well as $\left[{ }^{18} \mathrm{~F}\right] \mathrm{FPEB},\left[{ }^{11} \mathrm{C}\right] \mathrm{ABP} 688$, and $\left[{ }^{18} \mathrm{~F}\right] \mathrm{PSS} 232$ for mGluR5 [167-169]. In patients with AD, PET using $\left[{ }^{18} \mathrm{~F}\right] \mathrm{FPEB}[170]$ and $\left[{ }^{11} \mathrm{C}\right] \mathrm{ABP} 688$ [171] revealed consistent reductions in regional mGluR5 binding in the hippocampus and amygdala, compared with 
non-demented controls. Sofar only mGluR5 imaging has been reported in amyloidosis animal models and showed conflicting results probably due to different animal models utilized (Table 2). Lee et al. demonstrated an age-dependent 35\% decrease in the level of $\left[{ }^{18} \mathrm{~F}\right] \mathrm{FPEB}$ measures of mGluR5 in the cortical and subcortical brain areas in $5 \times$ FAD mice at 9 months of age, compared with 3 months of age, validated by ex vivo assessment of mGluR5 protein expression levels [116]. However, Varlow et al. showed that $\left[{ }^{18} \mathrm{~F}\right] \mathrm{FPEB}$ uptake increased in the brain of 10-month-old APP/PS1 mice, compared with controls [118]. Fang et al. reported similar levels of $\left[{ }^{18} \mathrm{~F}\right] \mathrm{FPEB}$ uptake in the brain of Tg-ArcSwe mice, compared with control mice at different ages [119]. However, immunoblotting results indicated that the level of mGluR5 in Tg-ArcSwe mouse brain lysate was higher, compared with control mice, at 12 months of age, not at 8 and 16 months of age [119]. Further studies are needed to elucidate the dynamic alteration in glutamate receptors in $\mathrm{AD}$ animal models.

\subsection{Cholinergic System}

The cholinergic system is essential for learning, memory formation, attention, and regulating inflammation [172]. The cholinergic system includes nicotinic acetylcholine receptors (nAChR), muscarinic acetylcholine receptors (mAChR), acetylcholinesterase (AChE), and butyrylcholinesterase (BChE). $\alpha 7 \mathrm{nAChR}$ and $\alpha 4 \beta 2 \mathrm{nAChR}$ are the most abundant $\mathrm{nAChR}$ subtypes in the brain. The cholinergic system is impaired early in $\mathrm{AD}$ associated with the cognitive, behavioral, and global functioning decline [172-174]. Reduced basal forebrain cholinergic neurons, increased levels of $\alpha 7 \mathrm{nAChR}[175,176]$, and reduced levels of M1 mAChR [177] were reported in the cortical regions of post-mortem brain from $\mathrm{AD}$ patients, compared with control. Interaction between $\alpha 7$ and $\alpha 4 \beta 2 \mathrm{nAChR}$ and different forms of $A \beta$ aggregates have also been reported [178-181]. Several recent PET tracers, including $\left[{ }^{11} \mathrm{C}\right] \mathrm{NS} 14492$ [182], $\left[{ }^{11} \mathrm{C}\right](\mathrm{R}) \mathrm{MeQAA}[69]$, and $\left[{ }^{18} \mathrm{~F}\right] \mathrm{ASEM}$ for $\alpha 7$ nAChR [183], $\left[{ }^{11} \mathrm{C}\right](+) 3-\mathrm{MPB}[184]$ and $\left[{ }^{18} \mathrm{~F}\right]$ fluorobenzyl-dexetimide [185] for $\mathrm{mAChR}$, $\left[{ }^{11} \mathrm{C}\right]$ LSN3172176 [186] for M1 mAChR, and [ $\left.{ }^{11} \mathrm{C}\right] \mathrm{MK}-6884$ for M4 mAChR [187] have been developed (Table 2). PET using $\left[{ }^{11} \mathrm{C}\right]$ nicotine imaging showed that the cortical $\mathrm{nAChR}$ binding correlated with the cognitive function of attention in patients with mild AD [188]. Few in vivo PET studies for the cholinergic system have been performed in AD models. Nishiyama et al. demonstrated higher $\left[{ }^{11} \mathrm{C}\right](\mathrm{R})$-MeQAA brain uptake in the thalamus, hippocampus, striatum, and cortical regions, along with increased $\left[{ }^{11} \mathrm{C}\right] \mathrm{PiB}$ detection of $\mathrm{A} \beta$ load and impaired $\left[{ }^{18} \mathrm{~F}\right] \mathrm{BCPP}-\mathrm{EF}$ binding to mitochondrial complex 1 in the brain of aged monkey [69]. Chaney et al. demonstrated lower levels of $\left[{ }^{18} \mathrm{~F}\right] \mathrm{ASEM}$ in TgF334 rats, compared with wild-type at 18 months of age [80]. Rejc et al. recently reported increased levels of $\mathrm{BChE}$ along with $\mathrm{A} \beta$ accumulation using $\left[{ }^{11} \mathrm{C}\right] 4$ and $\left[{ }^{18} \mathrm{~F}\right]$ florbetaben, respectively, in brain of $5 \times$ FAD mice at $4-12$ months of age, compared with wild-type mice [121] (Figure 2h-j). In comparison, comparable levels of AChE were observed in APP23, compared with wild-type mice at 10-13 months of age, assessed by PET using $\left[{ }^{11} \mathrm{C}\right] \mathrm{MP} 4 \mathrm{~A}[120]$.

\section{Blood-Brain Barrier}

Blood-brain barrier (BBB) is impaired at an early disease stage in AD $[189,190]$. Whether the BBB dysfunction is secondary to $A \beta$ pathology or a causal factor has not been fully elucidated. In amyloidosis animal models of AD, BBB disruption is observed in mouse models such as arcA $\beta$ and APP/PS1 but not prevalent in certain mouse lines such as the PS2APP line [191,192]. Several receptors presented in the BBB have been explored as PET imaging targets, such as adenosine triphosphate-binding cassette $(A B C)$ transporter ABCC1, ABCG2, ABCB1 (P-glycoprotein, P-gp), and receptor for advanced glycation endproducts (RAGE). P-gp plays an important role in the clearance and efflux of $A \beta$ from the brain into the blood across the brain endothelial luminal membrane [193]. The levels of P-gp expression and activity were found to be decreased in the brains of AD patients, compared with that in control cases, as well as in the APP mouse model, compared with wild-type mice [194]. Several P-gp tracers such as (R)-O- $\left[{ }^{18} \mathrm{~F}\right]$ fluoroethylnorverapamil, (R)- 
$\mathrm{N}-\left[{ }^{18} \mathrm{~F}\right]$ fluoroethylverapamil, (R)-[ $\left[{ }^{11} \mathrm{C}\right]$ verapamil, $\left[{ }^{11} \mathrm{C}\right]$ tariquidar, $\left[{ }^{11} \mathrm{C}\right]$ metoclopramide, and $\left[{ }^{18}\right.$ F]MC225 have been developed [130-133,195-198] (Table 2). Zoufal et al. demonstrated an age-dependent reduction in the cerebral P-gp function in APP/PS1 mice, compared with wild-type mice assessed by PET using $(R)-\left[{ }^{11} \mathrm{C}\right]$ verapamil [133] (Figure 3a-d) and by using $\left[{ }^{11} \mathrm{C}\right]$ metoclopramide [132].

However, $(R)-\left[{ }^{11} C\right]$ verapamil showed suboptimal brain uptake, and further improvement and evaluation of $\mathrm{P}$-gp function using novel tracers with improved properties are needed. In addition, PET using 6-bromo-7-[ $\left[{ }^{11} \mathrm{C}\right]$ methylpurine $\left(\left[{ }^{11} \mathrm{C}\right] \mathrm{BMP}\right)$ showed an increased level of $\mathrm{ABCC} 1$ along with $\left[{ }^{11} \mathrm{C}\right] \mathrm{PiB}$ detection of an increased level of $\mathrm{A} \beta$ pathology in the brain of APP/PS1 mice, compared with wild-type mice [130]. The increase in the $\mathrm{ABCC} 1$ level has been assumed to be related to the upregulation of its expression in astrocytes as a protective mechanism. Imaging of ABCG2 by PET using $\left[{ }^{11} \mathrm{C}\right]$ erlotinib has been reported in APP/PS1 mice: no alteration in the level of ABCG2, compared with wild-type mice, was observed [131].

Receptor for advanced glycation end products (RAGE) is a BBB transporter and a binding site for advanced glycation end products and mediates $A \beta$ transportation across the BBB into the brain $[199,200]$. The expression level of RAGE was found increased in post-mortem AD brains, compared with that in control cases [199]. RAGE tracers such as $\left[{ }^{11} \mathrm{C}\right]$ FPS-ZM1 [201], $\left[{ }^{18}\right.$ F]RAGER [202], $\left[{ }^{18} \mathrm{~F}\right]$ InRAGER [203], and $\left[{ }^{64} \mathrm{Cu}\right.$ ]Rho-G4-CML nanoparticle (multimodal) have been developed [204]. The only imaging study conducted in the AD animal model by Luzi et al. showed that $\left[{ }^{11} \mathrm{C}\right]$ FPS-ZM1 uptake in the brain of APPswe was similar, compared with that of wild-type mice [129]. Further development and studies are needed to evaluate RAGE imaging tracers in AD animal models and in patients with AD.
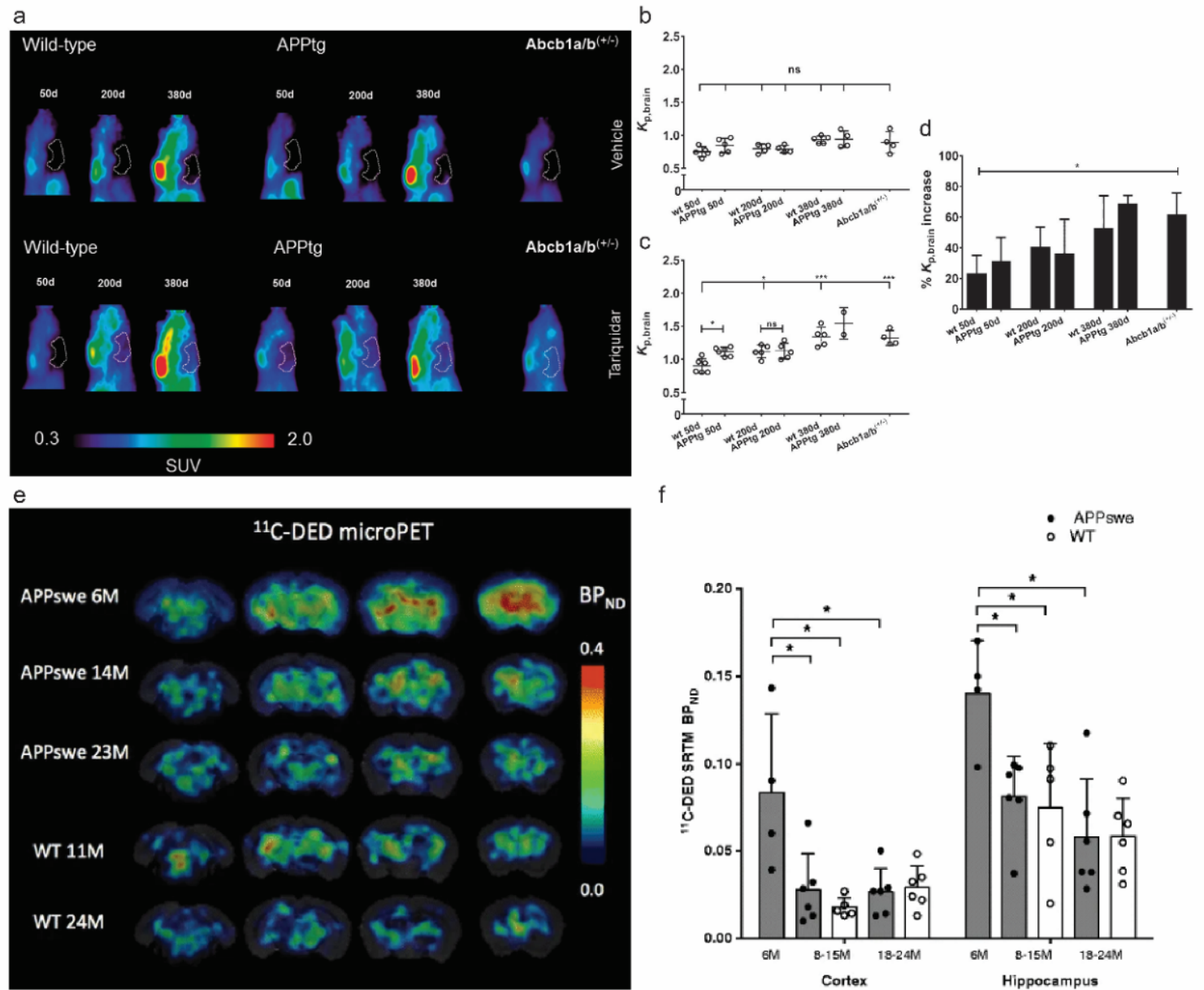

Figure 3. Cont. 

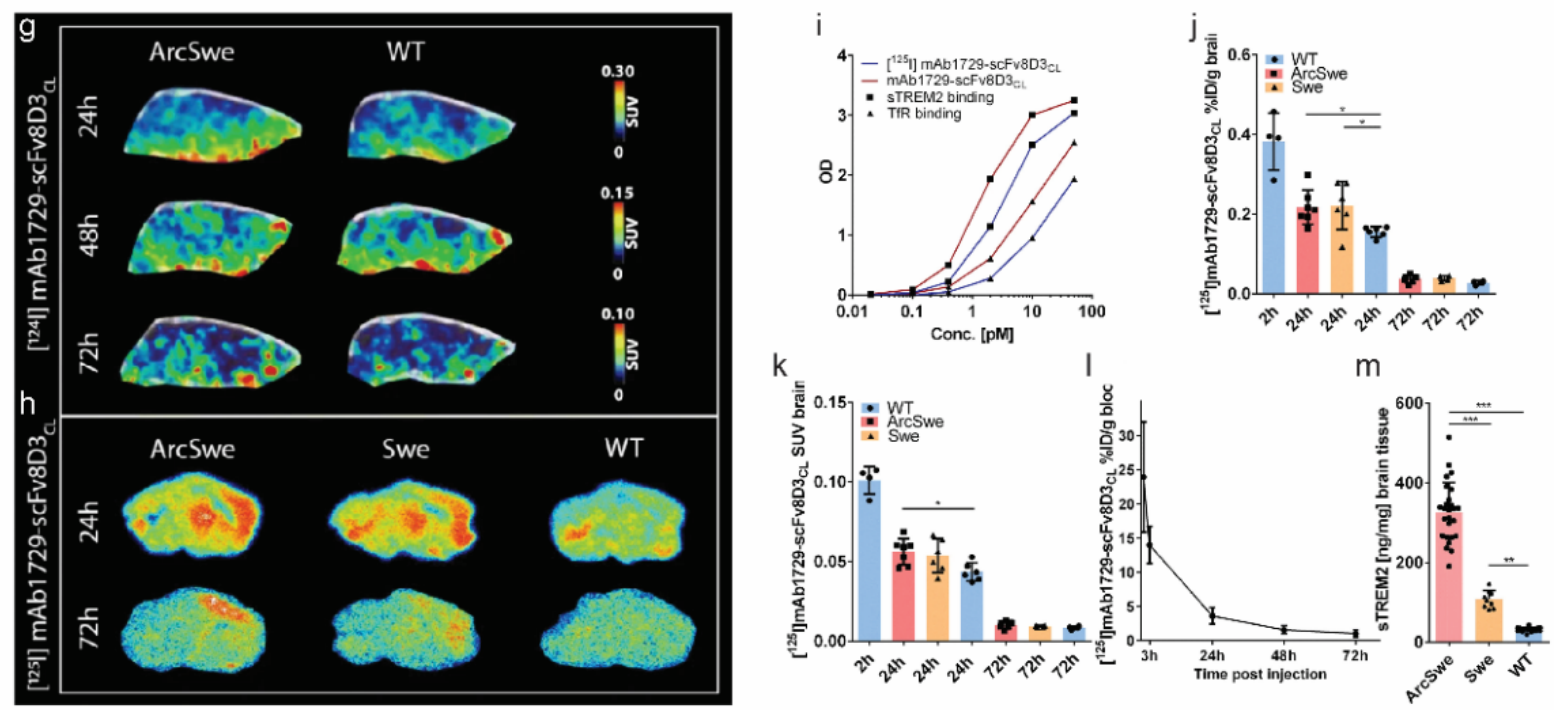

Figure 3. In vivo imaging of blood-brain barrier, astrocytosis, and triggering receptors expressed on myeloid cells (TREM) 2 in amyloidosis animal models of Alzheimer's disease: (a-d) imaging of P-glycoprotein (P-gp, ABCB1) using (R)-[ $\left.{ }^{11} \mathrm{C}\right]$ verapamil; (a) sagittal PET summation images (0-60 min) of wild-type and APP/PS1 mice aged 50, 200 and 380 days and $\mathrm{Abcb1a} / \mathrm{b}^{(+/-)}$mice pre-treated i.v. with vehicle $(\mathbf{b})$ or tariquidar $(4 \mathrm{mg} / \mathrm{kg})(\mathbf{c})$ at $2 \mathrm{~h}$ before start of the PET scan. The whole-brain region is highlighted as a white line. In (d), the mean percentage increase in Kp, brain of individual tariquidar-treated animals relative to mean $\mathrm{Kp}$, brain value of vehicle group is shown. Ns: not significant, ${ }^{*} p<0.05$, ${ }^{* * *} p<0.001$. Reproduced from [133] from Sage Publication; $(\mathbf{e}, \mathbf{f})\left[{ }^{11} \mathrm{C}\right]$ deuterium-l-deprenyl $\left(\left[{ }^{11} \mathrm{C}\right] \mathrm{DED}\right)$ microPET imaging in APPswe and wild-type (WT) mice: (e) $\left[{ }^{11} \mathrm{C}\right] \mathrm{DED}$ microPET coronal parametric $\mathrm{BP}_{\mathrm{ND}}$ maps images; (f) $\left[{ }^{11} \mathrm{C}\right] \mathrm{DED}$ binding in the cortex and hippocampus, expressed as $\mathrm{BP}_{\mathrm{ND}}$, obtained from simplified reference tissue model of $\left[{ }^{11} \mathrm{C}\right] \mathrm{DED}$ using the cerebellum as a reference region, in three groups of APPswe mice aged 6-, 8-15, and 18-24 months and two groups of wild-type mice aged 8-15 and 18-24 months. Significant differences between groups are indicated by * $p<0.05$. Reproduced from [82] with permission from Springer Nature; (g-m) PET imaging of triggering receptor expressed on myeloid cells 2 (TREM2) level in ArcSwe, Swe, and wild-type mice; (g) representative SUV scaled sagittal PET images with [ $\left.{ }^{124} \mathrm{I}\right] \mathrm{mAb} 1729-$ scFv8D3CL at $24 \mathrm{~h}, 48 \mathrm{~h}$, and $72 \mathrm{~h}$ after injection; (h) radioligand distribution in brain tissue displayed in sagittal ex vivo autoradiography images in ArcSwe, Swe, and wild-type animals at $24 \mathrm{~h}$ and $72 \mathrm{~h}$ after injection (h); (i) binding comparison of [ $\left.{ }^{125} \mathrm{I}\right] \mathrm{mAb} 1729-\mathrm{scFv} 8 \mathrm{D} 3 \mathrm{CL}$ and unlabelled mAb1729-scFv8D3CL by using ELISA. Percent of injected dose (j) and SUV (k) of $\left[{ }^{125} \mathrm{I}\right] \mathrm{mAb} 1729-\mathrm{scF}$ 8D3CL in brain $2 \mathrm{~h}, 24 \mathrm{~h}$, and $72 \mathrm{~h}$ after injection; (1) level of [ $\left.{ }^{124} \mathrm{I}\right] \mathrm{mAb} 1729-\mathrm{scFv} 8 \mathrm{D} 3 \mathrm{CL}$ in blood, which was sampled $1 \mathrm{~h}, 3 \mathrm{~h}, 24 \mathrm{~h}, 48 \mathrm{~h}$, and $72 \mathrm{~h}$ after injection; (m) TREM2 levels in TBS extracted brains of ArcSwe, APPSwe, and wild-type mice at the age of 18 months. Reproduced from [205] with permission from Springer Nature.

\section{Neuroinflammation Imaging}

Several recent articles have provided thorough reviews on neuroinflammation PET imaging in AD patients and AD animal models [206-211]. Thus, here, we discuss briefly the recent development in neuroinflammation imaging in AD amyloidosis animal models. Neuroinflammation plays an important role in the pathogenesis of AD and appears early in the development of the disease [212-214]. Microglia are the resident macrophages in the central nervous system, engulf $A \beta$ plaques, and are important for maintaining brain homeostasis [214,215]. Recent single-cell sequencing and transcriptomics have demonstrated a transcriptionally distinct and neurodegeneration-specific profile of microglia termed diseaseassociated microglia (DAM) [216-218]. The $18 \mathrm{kDa}$ translocator protein (TSPO) located on the outer mitochondria membrane of microglia has been the most investigated target for microgliosis PET imaging. Three generations of TSPO tracers have been developed with improved properties: the first-generation (R)-[ $\left.{ }^{11} \mathrm{C}\right] \mathrm{PK} 11195$ [219]; the second-generation $\left[{ }^{11} \mathrm{C}\right]$ PBR28 [220], $\left[{ }^{18} \mathrm{~F}\right]$ FEDAA1106 [68], [ $\left.{ }^{18} \mathrm{~F}\right] \mathrm{DPA}-714$ [105]; the third-generation [ $\left.{ }^{18} \mathrm{~F}\right] \mathrm{GE}-$ 180 [134] (Figure 2a) and [ $\left.{ }^{11} \mathrm{C}\right] \mathrm{ER} 176$ [221]. PET using various $18 \mathrm{kDa}$ translocator protein (TSPO) tracers have demonstrated an early microgliosis preceding the A $\beta$ deposition in 
several animal models of amyloidosis including APP23, hAPP-J20, APPSL70, App ${ }^{\text {NL-G-F, }}$ and PS2APP mice $[76,77,215,222-225]$. Sacher et al. showed an asymmetry and hemispheric predominance of $A \beta$ accumulation detected by using $\left[{ }^{18} \mathrm{~F}\right]$ florbetaben accompanied by microglial activation assessed by using $\left[{ }^{18} \mathrm{~F}\right] \mathrm{GE}-180$ in five mouse lines, including APP/PS1, PS2APP, APP-SL70, APPswe transgenic mice, and App ${ }^{\text {NL-G-F }}$ knock-in mice $[74,226]$. Due to the diverse cellular location of TSPO expression on astrocytes and endothelial cells, in addition to that on microglia, tracers specific for microglial expression and of the diseaseassociated profile are of high interest [227-229]. Emerging targets and tracers include $\left[{ }^{11} \mathrm{C}\right]$ SW125M139 for purinergic P2X7 receptor [230,231], [ $\left.{ }^{124} \mathrm{I}\right] \mathrm{mAb} 1729-\mathrm{scFv} 8 \mathrm{D} 3 \mathrm{CL}$ for triggering receptors expressed on myeloid cells (TREM) 2, $\left[{ }^{11} \mathrm{C}\right] \mathrm{AZD} 1283$ for purinergic P2Y12 receptor [232], $\left.{ }^{[1} \mathrm{C}\right] \mathrm{CPPC}[233]$ and $\left[{ }^{11} \mathrm{C}\right] \mathrm{GW} 2580$ [234] for colony-stimulating factor 1 receptor, $\left[{ }^{11} \mathrm{C}\right] \mathrm{KTP}-\mathrm{Me}$ for cyclooxygenase 1 [235] have been reported in $\mathrm{AD}$ animal models. Meier et al. showed a higher expression level of triggering receptor expressed on myeloid cells 2 (TREM2) in the brain from ArcSwe mice, compared with wild-type mice at $24 \mathrm{~h}, 48 \mathrm{~h}$, and $72 \mathrm{~h}$ after injection by autoradiography using [ $\left.{ }^{124} \mathrm{I}\right] \mathrm{mAb} 1729-$ scFv8D3CL [205] (Figure 3g-m). The tracers for purinergic P2Y12 receptor [232] show a more specific microglial localization and thus are of high potential.

\section{Discussion}

In vivo longitudinal imaging in animal models of $\mathrm{AD}$ amyloidosis has provided valuable insights on the spatiotemporal links between different pathophysiology. A range of molecular imaging tracers for neuroinflammation, synaptic density, and neurotransmitter receptor deficits have been developed and provided a comprehensive picture of $\mathrm{AD}[11,210,236,237]$. In addition to the aforementioned targets, many emerging targets show potential as indicators for pathological alterations in $\mathrm{AD}$ and are yet to be further investigated in amyloidosis animal models. These include (1) microgliosis; (2) astrocytosis; (3) metal dysregulation and copper trafficking, e.g., using [ $\left.{ }^{64} \mathrm{Cu}\right]$ GTSM [125]; (4) reactive oxygen species [238] and $\mathrm{pH}$ alterations [239]; (5) microtubule using $\left[{ }^{11} \mathrm{C}\right] \mathrm{MPC}-6827$, $\left[{ }^{11} \mathrm{C}\right] \mathrm{HD}-800,\left[{ }^{11} \mathrm{C}\right] \mathrm{WX}-132-18 \mathrm{~B}[126,240,241]$; (6) sigma 1 receptor using $\left[{ }^{11} \mathrm{C}\right] \mathrm{HCC} 0929$, $\left[{ }^{18} \mathrm{~F}\right] \mathrm{FTC}-146,\left[{ }^{18} \mathrm{~F}\right] \mathrm{IAM} 6067$ and $\left[{ }^{11} \mathrm{C}\right] \mathrm{SA} 4503$ [242-244]; (7) mitochondria imaging using $\left[{ }^{18} \mathrm{~F}\right] \mathrm{BCPP}-\mathrm{EF}[123]$; 8) glycogen synthase kinase-3 imaging using $\left[{ }^{11} \mathrm{C}\right] 2,\left[{ }^{11} \mathrm{C}\right] \mathrm{OCM}-44$, $\left[{ }^{3} \mathrm{H}\right] \mathrm{PF}-367[128,245]$.

Among the aforementioned emerging microgliosis tracers, the tracers for purinergic P2X7 receptor [230,231], P2Y12 receptor [232] are of high interest due to their specific cellular location on microglia. In addition, astrocytes are essential for maintaining the homeostasis, synaptic plasticity, and inflammatory response in the central nervous system [246] and play key roles in the onset and progression of AD. Reactive astrocytes show diseaseassociated profiles and exert dynamic functions (neuroprotection and neurotoxicity) in $\mathrm{AD}$ [247-251]. Few studies have been reported on PET imaging of astrocytosis in AD animal models. PET using irreversible monoamine oxidase B (MAO-B) inhibitors $\left[{ }^{11} \mathrm{C}\right]$ deuteriumL-deprenyl (DED) showed an early astrocytosis preceding the $A \beta$ accumulation assessed by using $\left[{ }^{11} \mathrm{C}\right] \mathrm{AZD} 2184$ in the brain of APPswe at 6 months of age, compared with wild-type mice (Figure $3 \mathrm{e}, \mathrm{f})$. A similar finding of an early increase in $\left[{ }^{11} \mathrm{C}\right] \mathrm{DED}$ binding was reported in Tg-ArcSwe mice, compared with wild-type littermates [252]. Several novel MAO-B tracers have been developed including $\left[{ }^{11} \mathrm{C}\right] \mathrm{SMBT}-1$ [253] based on $(S)-\left[{ }^{18} \mathrm{~F}\right] \mathrm{THK} 5117$ structure [254] and $\left[{ }^{18} \mathrm{~F}\right] 6$ [255]. In addition, a novel astrocytic tracer $\left[{ }^{11} \mathrm{C}\right] \mathrm{BU} 99008$, which targets imidazoline-2 binding sites (I2BS), has shown specific and high-affinity binding properties in post-mortem characterization [256] and demonstrated promising results in the recent in vivo PET studies in patients with $\operatorname{AD}[257,258]$.

Several earlier studies have reported the complicated temporal and spatial association between $\left[{ }^{18} \mathrm{~F}\right] \mathrm{FDG}, \mathrm{TSPO}$, and amyloid accumulation: reduced $\left[{ }^{18} \mathrm{~F}\right] \mathrm{FDG}$ uptake, increased $\mathrm{A} \beta$ deposition using $\left[{ }^{11} \mathrm{C}\right] \mathrm{PiB}$ or $\left[{ }^{18} \mathrm{~F}\right]$ florbetaben $[64,134]$, and increased microglial activation using $\left[{ }^{18} \mathrm{~F}\right] \mathrm{GE}-180$ [134] (Figure 2a-d), and $\left[{ }^{18} \mathrm{~F}\right] \mathrm{DPA}-714$ has been reported in animal models [105]. Tsukada et al. reported reduced $\left[{ }^{18} \mathrm{~F}\right] \mathrm{FDG}$ uptake, increased $\left[{ }^{11} \mathrm{C}\right] \mathrm{PiB}$ 
measures of $A \beta$ deposition, increased $\left[{ }^{11} \mathrm{C}\right] \mathrm{DPA}-713$ for microglia activation, and reduced $\left[{ }^{18} \mathrm{~F}\right] \mathrm{BCPP}-\mathrm{EF}$ for mitochondrial complex 1 in the brain of aged monkeys [70]. Given the recent finding of microglial $\left[{ }^{18} \mathrm{~F}\right] \mathrm{FDG}$-PET uptake [97], further studies may potentially use $\left[{ }^{18} \mathrm{~F}\right] \mathrm{FDG}-\mathrm{PET}$ for monitoring the microglial status in treatment targeting at microglia. In addition, markers that can specifically reflect synaptic and neuronal function are needed. Amyloidosis animal models show cortical, hippocampal atrophy, and enlargement of ventricle assessed by using structural magnetic resonance imaging, although to a less extent, compared with that in tauopathy animal models $[259,260]$. Multi-modal imaging [261] or multi-tracer imaging studies combining microgliosis, $\left[{ }^{18} \mathrm{~F}\right] \mathrm{FDG}$, and SV2A imaging to provide more comprehensive functional and molecular readouts are thus highly desired [262].

The challenges in bridging the translational gaps of PET imaging in rodent models and in patients with AD may include (1) different rodent models of AD demonstrated divergent time courses and patterns of pathophysiological development. Thus, rational selection of optimal animal models and age for investigation is thus critical in PET imaging studies in tracer evaluation [263]; (2) in addition, species difference in cell types, protein expression level, available binding sites, and post-translational modification of the target added to the complexity [264]. For example, the A $\beta$ deposits formed in the APP mouse models and in aged primates are structurally different from that in the brain from patients with $\mathrm{AD}$ [265]. Thus, models that better recapitulate the human AD pathology will greatly boost the $\mathrm{AD}$ research, such as the A $\beta-\mathrm{KI}$ mouse modeling late-onset $\mathrm{AD}$ [23] and the thirdgeneration mouse model [22]; databases of comprehensive deep phenotyping in disease animal models such as "MODEL-AD" by the Alzheimer Consortium Think Tank [266,267] (www.model-ad.org/, accessed on 15 October 2021) are instrumental in facilitating the translational research. Systems biology approaches, including single-cell sequencing, transcriptomics, biochemical characterization, and behavioral assessments, along with in vivo imaging data, will provide accurate interpretation of the readouts [268].

\section{Conclusions}

We provided an overview of PET imaging in animal models of AD amyloidosis, highlighting recent development in visualizing $A \beta$, cerebral glucose metabolism, synaptic and neurotransmitter receptor deficits, BBB impairment, and neuroinflammation, and proposed outstanding challenges for future development to increase the translational power of preclinical PET in AD.

Funding: R.N. received funding from Helmut Horten Stiftung, Vontobel Stiftung.

Institutional Review Board Statement: Not applicable.

Informed Consent Statement: Not applicable.

Data Availability Statement: All data are contained within the article.

Conflicts of Interest: The author declares no conflict of interest.

\section{References}

1. Bhatt, J.; Comas Herrera, A.; Amico, F.; Farina, N.; Wong, J.; Orange, J.B.; Gaber, S.; Knapp, M.; Salcher-Konrad, M.; Stevens, M.; et al. The World Alzheimer Report 2019: Attitudes to Dementia; Alzheimer's Disease International: London, UK, 2019.

2. Scheltens, P.; De Strooper, B.; Kivipelto, M.; Holstege, H.; Chételat, G.; Teunissen, C.E.; Cummings, J.; van der Flier, W.M. Alzheimer's disease. Lancet 2021, 397, 1577-1590. [CrossRef]

3. Lesné, S.; Koh, M.T.; Kotilinek, L.; Kayed, R.; Glabe, C.G.; Yang, A.; Gallagher, M.; Ashe, K.H. A specific amyloid- $\beta$ protein assembly in the brain impairs memory. Nature 2006, 440, 352-357. [CrossRef] [PubMed]

4. Haass, C.; Selkoe, D.J. Soluble protein oligomers in neurodegeneration: Lessons from the Alzheimer's amyloid beta-peptide. Nat. Rev. Mol. Cell Biol. 2007, 8, 101-112. [CrossRef] [PubMed]

5. Lambert, M.P.; Velasco, P.T.; Chang, L.; Viola, K.L.; Fernandez, S.; Lacor, P.N.; Khuon, D.; Gong, Y.; Bigio, E.H.; Shaw, P.; et al. Monoclonal antibodies that target pathological assemblies of A $\beta$. J. Neurochem. 2007, 100, 23-35. [CrossRef] [PubMed] 
6. Shankar, G.M.; Li, S.; Mehta, T.H.; Garcia-Munoz, A.; Shepardson, N.E.; Smith, I.; Brett, F.M.; Farrell, M.A.; Rowan, M.J.; Lemere, C.A.; et al. Amyloid- $\beta$ protein dimers isolated directly from Alzheimer's brains impair synaptic plasticity and memory. Nat. Med. 2008, 14, 837-842. [CrossRef]

7. Jack, C.R., Jr.; Bennett, D.A.; Blennow, K.; Carrillo, M.C.; Dunn, B.; Haeberlein, S.B.; Holtzman, D.M.; Jagust, W.; Jessen, F.; Karlawish, J.; et al. NIA-AA Research Framework: Toward a biological definition of Alzheimer's disease. Alzheimers Dement. 2018, 14, 535-562. [CrossRef] [PubMed]

8. Cotta Ramusino, M.; Perini, G.; Altomare, D.; Barbarino, P.; Weidner, W.; Salvini Porro, G.; Barkhof, F.; Rabinovici, G.D.; van der Flier, W.M.; Frisoni, G.B.; et al. Outcomes of clinical utility in amyloid-PET studies: State of art and future perspectives. Eur. J. Nucl. Med. Mol. Imaging 2021, 48, 2157-2168. [CrossRef]

9. Chételat, G.; Arbizu, J.; Barthel, H.; Garibotto, V.; Law, I.; Morbelli, S.; van de Giessen, E.; Agosta, F.; Barkhof, F.; Brooks, D.J.; et al. Amyloid-PET and ${ }^{18}$ F-FDG-PET in the diagnostic investigation of Alzheimer's disease and other dementias. Lancet Neurol. 2020, 19, 951-962. [CrossRef]

10. Dubois, B.; Villain, N.; Frisoni, G.B.; Rabinovici, G.D.; Sabbagh, M.; Cappa, S.; Bejanin, A.; Bombois, S.; Epelbaum, S.; Teichmann, M.; et al. Clinical diagnosis of Alzheimer's disease: Recommendations of the International Working Group. Lancet Neurol. 2021, 20, 484-496. [CrossRef]

11. Perani, D.; Iaccarino, L.; Lammertsma, A.A.; Windhorst, A.D.; Edison, P.; Boellaard, R.; Hansson, O.; Nordberg, A.; Jacobs, A.H. A new perspective for advanced positron emission tomography-based molecular imaging in neurodegenerative proteinopathies. Alzheimers Dement. 2019, 15, 1081-1103. [CrossRef]

12. Radde, R.; Bolmont, T.; Kaeser, S.A.; Coomaraswamy, J.; Lindau, D.; Stoltze, L.; Calhoun, M.E.; Jaggi, F.; Wolburg, H.; Gengler, S.; et al. Abeta42-driven cerebral amyloidosis in transgenic mice reveals early and robust pathology. EMBO Rep. 2006, 7, 940-946. [CrossRef] [PubMed]

13. Hsiao, K.; Chapman, P.; Nilsen, S.; Eckman, C.; Harigaya, Y.; Younkin, S.; Yang, F.; Cole, G. Correlative memory deficits, Abeta elevation, and amyloid plaques in transgenic mice. Science 1996, 274, 99-102. [CrossRef] [PubMed]

14. Mucke, L.; Masliah, E.; Yu, G.Q.; Mallory, M.; Rockenstein, E.M.; Tatsuno, G.; Hu, K.; Kholodenko, D.; Johnson-Wood, K.; McConlogue, L. High-level neuronal expression of abeta 1-42 in wild-type human amyloid protein precursor transgenic mice: Synaptotoxicity without plaque formation. J. Neurosci. 2000, 20, 4050-4058. [CrossRef] [PubMed]

15. Richards, J.G.; Higgins, G.A.; Ouagazzal, A.M.; Ozmen, L.; Kew, J.N.; Bohrmann, B.; Malherbe, P.; Brockhaus, M.; Loetscher, H.; Czech, C.; et al. PS2APP transgenic mice, coexpressing hPS2mut and hAPPswe, show age-related cognitive deficits associated with discrete brain amyloid deposition and inflammation. J. Neurosci. 2003, 23, 8989-9003. [CrossRef] [PubMed]

16. Sturchler-Pierrat, C.; Abramowski, D.; Duke, M.; Wiederhold, K.H.; Mistl, C.; Rothacher, S.; Ledermann, B.; Bürki, K.; Frey, P.; Paganetti, P.A.; et al. Two amyloid precursor protein transgenic mouse models with Alzheimer disease-like pathology. Proc. Natl. Acad. Sci. USA 1997, 94, 13287-13292. [CrossRef]

17. Oakley, H.; Cole, S.L.; Logan, S.; Maus, E.; Shao, P.; Craft, J.; Guillozet-Bongaarts, A.; Ohno, M.; Disterhoft, J.; Van Eldik, L.; et al. Intraneuronal beta-amyloid aggregates, neurodegeneration, and neuron loss in transgenic mice with five familial Alzheimer's disease mutations: Potential factors in amyloid plaque formation. J. Neurosci. 2006, 26, 10129-10140. [CrossRef] [PubMed]

18. Oddo, S.; Caccamo, A.; Shepherd, J.D.; Murphy, M.P.; Golde, T.E.; Kayed, R.; Metherate, R.; Mattson, M.P.; Akbari, Y.; LaFerla, F.M. Triple-transgenic model of Alzheimer's disease with plaques and tangles: Intracellular Abeta and synaptic dysfunction. Neuron 2003, 39, 409-421. [CrossRef]

19. Ni, R.; Dean-Ben, X.L.; Kirschenbaum, D.; Rudin, M.; Chen, Z.; Crimi, A.; Voigt, F.F.; Nilsson, K.P.R.; Helmchen, F.; Nitsch, R. Whole brain optoacoustic tomography reveals strain-specific regional beta-amyloid densities in Alzheimer's disease amyloidosis models. bioRxiv 2020. [CrossRef]

20. Saito, T.; Matsuba, Y.; Mihira, N.; Takano, J.; Nilsson, P.; Itohara, S.; Iwata, N.; Saido, T.C. Single App knock-in mouse models of Alzheimer's disease. Nat. Neurosci. 2014, 17, 661-663. [CrossRef] [PubMed]

21. Serneels, L.; T'Syen, D.; Perez-Benito, L.; Theys, T.; Holt, M.G.; De Strooper, B. Modeling the $\beta$-secretase cleavage site and humanizing amyloid-beta precursor protein in rat and mouse to study Alzheimer's disease. Mol. Neurodegener. 2020, 15, 60. [CrossRef]

22. Sato, K.; Watamura, N.; Fujioka, R.; Mihira, N.; Sekiguchi, M.; Nagata, K.; Ohshima, T.; Saito, T.; Saido, T.C.; Sasaguri, H. A 3(rd) generation mouse model of Alzheimer's disease shows early and increased cored plaque pathology composed of wild-type human amyloid $\beta$ peptide. J. Biol. Chem. 2021, 297, 101004. [CrossRef] [PubMed]

23. Baglietto-Vargas, D.; Forner, S.; Cai, L.; Martini, A.C.; Trujillo-Estrada, L.; Swarup, V.; Nguyen, M.M.T.; Do Huynh, K.; Javonillo, D.I.; Tran, K.M.; et al. Generation of a humanized A $\beta$ expressing mouse demonstrating aspects of Alzheimer's disease-like pathology. Nat. Commun. 2021, 12, 2421. [CrossRef] [PubMed]

24. Latimer, C.S.; Shively, C.A.; Keene, C.D.; Jorgensen, M.J.; Andrews, R.N.; Register, T.C.; Montine, T.J.; Wilson, A.M.; Neth, B.J.; Mintz, A.; et al. A nonhuman primate model of early Alzheimer's disease pathologic change: Implications for disease pathogenesis. Alzheimer Dement. 2019, 15, 93-105. [CrossRef] [PubMed]

25. Whitesell, J.D.; Buckley, A.R.; Knox, J.E.; Kuan, L.; Graddis, N.; Pelos, A.; Mukora, A.; Wakeman, W.; Bohn, P.; Ho, A.; et al. Whole brain imaging reveals distinct spatial patterns of amyloid beta deposition in three mouse models of Alzheimer's disease. J. Comp. Neurol. 2019, 527, 2122-2145. [CrossRef] 
26. Liu, P.; Reichl, J.H.; Rao, E.R.; McNellis, B.M.; Huang, E.S.; Hemmy, L.S.; Forster, C.L.; Kuskowski, M.A.; Borchelt, D.R.; Vassar, R.; et al. Quantitative Comparison of Dense-Core Amyloid Plaque Accumulation in Amyloid- $\beta$ Protein Precursor Transgenic Mice. J. Alzheimers Dis. 2017, 56, 743-761. [CrossRef]

27. Sasaguri, H.; Nilsson, P.; Hashimoto, S.; Nagata, K.; Saito, T.; De Strooper, B.; Hardy, J.; Vassar, R.; Winblad, B.; Saido, T.C. APP mouse models for Alzheimer's disease preclinical studies. EMBO J. 2017, 36, 2473-2487. [CrossRef]

28. Robbins, E.M.; Betensky, R.A.; Domnitz, S.B.; Purcell, S.M.; Garcia-Alloza, M.; Greenberg, C.; Rebeck, G.W.; Hyman, B.T.; Greenberg, S.M.; Frosch, M.P.; et al. Kinetics of cerebral amyloid angiopathy progression in a transgenic mouse model of Alzheimer disease. J. Neurosci. 2006, 26, 365-371. [CrossRef]

29. Jäkel, L.; Van Nostrand, W.E.; Nicoll, J.A.R.; Werring, D.J.; Verbeek, M.M. Animal models of cerebral amyloid angiopathy. Clin. Sci. 2017, 131, 2469-2488. [CrossRef]

30. Ni, R.; Chen, Z.; Shi, G.; Villois, A.; Zhou, Q.; Arosio, P.; Nitsch, R.M.; Nilsson, K.P.R.; Klohs, J.; Razansky, D. Transcranial in vivo detection of amyloid-beta at single plaque resolution with large-field multifocal illumination fluorescence microscopy. bioRxiv 2020. [CrossRef]

31. Cheng, Y.; Ono, M.; Kimura, H.; Kagawa, S.; Nishii, R.; Saji, H. A novel ${ }^{18}$ F-labeled pyridyl benzofuran derivative for imaging of $\beta$-amyloid plaques in Alzheimer's brains. Bioorg. Med. Chem. Lett. 2010, 20, 6141-6144. [CrossRef]

32. Hostetler, E.D.; Sanabria-Bohórquez, S.; Fan, H.; Zeng, Z.; Gammage, L.; Miller, P.; O’Malley, S.; Connolly, B.; Mulhearn, J.; Harrison, S.T.; et al. $\left[{ }^{18}\right.$ F]Fluoroazabenzoxazoles as potential amyloid plaque PET tracers: Synthesis and in vivo evaluation in rhesus monkey. Nucl. Med. Biol. 2011, 38, 1193-1203. [CrossRef] [PubMed]

33. Snellman, A.; Rokka, J.; Lopez-Picon, F.R.; Helin, S.; Re, F.; Loyttyniemi, E.; Pihlaja, R.; Forloni, G.; Salmona, M.; Masserini, M.; et al. Applicability of [ $\left.{ }^{11} \mathrm{C}\right] \mathrm{PIB}$ micro-PET imaging for in vivo follow-up of anti-amyloid treatment effects in APP23 mouse model. Neurobiol. Aging 2017, 57, 84-94. [CrossRef] [PubMed]

34. Oh, S.J.; Lee, H.-J.; Kang, K.J.; Han, S.J.; Lee, Y.J.; Lee, K.C.; Lim, S.M.; Chi, D.Y.; Kim, K.M.; Park, J.-A.; et al. Early Detection of A $\beta$ Deposition in the 5xFAD Mouse by Amyloid PET. Contrast Media Mol. Imaging 2018, 2018, 5272014. [CrossRef]

35. Oh, S.J.; Kim, M.H.; Han, S.J.; Kang, K.J.; Ko, I.O.; Kim, Y.; Park, J.-A.; Choi, J.Y.; Lee, K.C.; Chi, D.Y.; et al. Preliminary PET Study of ${ }^{18}$ F-FC119S in Normal and Alzheimer's Disease Models. Mol. Pharm. 2017, 14, 3114-3120. [CrossRef] [PubMed]

36. Yousefi, B.H.; von Reutern, B.; Scherubl, D.; Manook, A.; Schwaiger, M.; Grimmer, T.; Henriksen, G.; Forster, S.; Drzezga, A.; Wester, H.J. FIBT versus florbetaben and PiB: A preclinical comparison study with amyloid-PET in transgenic mice. EJNMMI Res. 2015, 5, 20. [CrossRef]

37. Snellman, A.; Rokka, J.; Lopez-Picon, F.R.; Eskola, O.; Wilson, I.; Farrar, G.; Scheinin, M.; Solin, O.; Rinne, J.O.; Haaparanta-Solin, M. Pharmacokinetics of $\left[{ }^{18} \mathrm{~F}\right]$ flutemetamol in wild-type rodents and its binding to beta amyloid deposits in a mouse model of Alzheimer's disease. Eur. J. Nucl. Med. Mol. Imaging 2012, 39, 1784-1795. [CrossRef]

38. Snellman, A.; Rokka, J.; López-Picón, F.R.; Eskola, O.; Salmona, M.; Forloni, G.; Scheinin, M.; Solin, O.; Rinne, J.O.; HaaparantaSolin, M. In vivo PET imaging of beta-amyloid deposition in mouse models of Alzheimer's disease with a high specific activity PET imaging agent $\left[{ }^{18}\right.$ F]flutemetamol. EJNMMI Res. 2014, 4, 37. [CrossRef]

39. Huang, Y.; Cho, H.-J.; Bandara, N.; Sun, L.; Tran, D.; Rogers, B.E.; Mirica, L.M. Metal-chelating benzothiazole multifunctional compounds for the modulation and 64Cu PET imaging of A $\beta$ aggregation. Chem. Sci. 2020, 11, 7789-7799. [CrossRef]

40. Xu, M.; Guo, J.; Gu, J.; Zhang, L.; Liu, Z.; Ding, L.; Fu, H.; Ma, Y.; Liang, S.; Wang, H. Preclinical and clinical study on $\left[{ }^{18}\right.$ F]DRKXH1: A novel $\beta$-amyloid PET tracer for Alzheimer's disease. Eur. J. Nucl. Med. Mol. Imaging 2021, 1-12. [CrossRef]

41. Liang, S.H.; Holland, J.P.; Stephenson, N.A.; Kassenbrock, A.; Rotstein, B.H.; Daignault, C.P.; Lewis, R.; Collier, L.; Hooker, J.M.; Vasdev, N. PET neuroimaging studies of $\left[{ }^{18} \mathrm{~F}\right] \mathrm{CABS} 13$ in a double transgenic mouse model of Alzheimer's disease and nonhuman primates. ACS Chem. Neurosci. 2015, 6, 535-541. [CrossRef]

42. Juréus, A.; Swahn, B.M.; Sandell, J.; Jeppsson, F.; Johnson, A.E.; Johnström, P.; Neelissen, J.A.; Sunnemark, D.; Farde, L.; Svensson, S.P. Characterization of AZD4694, a novel fluorinated Abeta plaque neuroimaging PET radioligand. J. Neurochem. 2010, 114, 784-794. [CrossRef]

43. Parent, M.J.; Zimmer, E.R.; Shin, M.; Kang, M.S.; Fonov, V.S.; Mathieu, A.; Aliaga, A.; Kostikov, A.; Do Carmo, S.; Dea, D.; et al. Multimodal Imaging in Rat Model Recapitulates Alzheimer's Disease Biomarkers Abnormalities. J. Neurosci. 2017, 37, 12263-12271. [CrossRef] [PubMed]

44. Cho, H.J.; Huynh, T.T.; Rogers, B.E.; Mirica, L.M. Design of a multivalent bifunctional chelator for diagnostic (64)Cu PET imaging in Alzheimer's disease. Proc. Natl. Acad. Sci. USA 2020, 117, 30928-30933. [CrossRef] [PubMed]

45. Ni, R.; Villois, A.; Dean-Ben, X.L.; Chen, Z.; Vaas, M.; Stavrakis, S.; Shi, G.; deMello, A.; Ran, C.; Razansky, D.; et al. In-vitro and in-vivo characterization of CRANAD-2 for multi-spectral optoacoustic tomography and fluorescence imaging of amyloid-beta deposits in Alzheimer mice. Photoacoustics 2021, 23, 100285. [CrossRef] [PubMed]

46. Ni, R.; Gillberg, P.-G.; Bogdanovic, N.; Viitanen, M.; Myllykangas, L.; Nennesmo, I.; Långström, B.; Nordberg, A. Amyloid tracers binding sites in autosomal dominant and sporadic Alzheimer's disease. Alzheimer Dement. 2017, 13, 419-430. [CrossRef]

47. Ni, R.; Röjdner, J.; Voytenko, L.; Dyrks, T.; Thiele, A.; Marutle, A.; Nordberg, A. In vitro Characterization of the Regional Binding Distribution of Amyloid PET Tracer Florbetaben and the Glia Tracers Deprenyl and PK11195 in Autopsy Alzheimer's Brain Tissue. J. Alzheimers Dis. 2021, 80, 1723-1737. [CrossRef] 
48. Snellman, A.; López-Picón, F.R.; Rokka, J.; Salmona, M.; Forloni, G.; Scheinin, M.; Solin, O.; Rinne, J.O.; Haaparanta-Solin, M. Longitudinal amyloid imaging in mouse brain with ${ }^{11}$ C-PIB: Comparison of APP23, Tg2576, and APPswe-PS1dE9 mouse models of Alzheimer disease. J. Nucl. Med. 2013, 54, 1434-1441. [CrossRef]

49. Brendel, M.; Jaworska, A.; Grießinger, E.; Rötzer, C.; Burgold, S.; Gildehaus, F.J.; Carlsen, J.; Cumming, P.; Baumann, K.; Haass, C.; et al. Cross-sectional comparison of small animal $\left[{ }^{18} \mathrm{~F}\right]$-florbetaben amyloid-PET between transgenic AD mouse models. PLoS ONE 2015, 10, e0116678. [CrossRef]

50. Son, H.J.; Jeong, Y.J.; Yoon, H.J.; Lee, S.Y.; Choi, G.-E.; Park, J.-A.; Kim, M.H.; Lee, K.C.; Lee, Y.J.; Kim, M.K.; et al. Assessment of brain beta-amyloid deposition in transgenic mouse models of Alzheimer's disease with PET imaging agents ${ }^{18} \mathrm{~F}-\mathrm{flutemetamol}$ and ${ }^{18}$ F-florbetaben. BMC Neurosci. 2018, 19, 45. [CrossRef]

51. Catafau, A.M.; Bullich, S. Amyloid PET imaging: Applications beyond Alzheimer's disease. Clin. Transl. Imaging 2015, 3, 39-55. [CrossRef]

52. Han, B.H.; Zhou, M.-1.; Vellimana, A.K.; Milner, E.; Kim, D.H.; Greenberg, J.K.; Chu, W.; Mach, R.H.; Zipfel, G.J. Resorufin analogs preferentially bind cerebrovascular amyloid: Potential use as imaging ligands for cerebral amyloid angiopathy. Mol. Neurodegener. 2011, 6, 86. [CrossRef] [PubMed]

53. Abrahamson, E.E.; Stehouwer, J.S.; Vazquez, A.L.; Huang, G.-F.; Mason, N.S.; Lopresti, B.J.; Klunk, W.E.; Mathis, C.A.; Ikonomovic, M.D. Development of a PET radioligand selective for cerebral amyloid angiopathy. Nucl. Med. Biol. 2021, 92, 85-96. [CrossRef]

54. Biechele, G.; Sebastian Monasor, L.; Wind, K.; Blume, T.; Parhizkar, S.; Arzberger, T.; Sacher, C.; Beyer, L.; Eckenweber, F.; Gildehaus, F.J.; et al. Glitter in the Darkness? Non-fibrillar $\beta$-amyloid Plaque Components Significantly Impact the $\beta$-amyloid PET Signal in Mouse Models of Alzheimer's Disease. J. Nucl. Med. 2021, 62. [CrossRef] [PubMed]

55. Meier, S.R.; Sehlin, D.; Roshanbin, S.; Lim Falk, V.; Saito, T.; Saido, T.C.; Neumann, U.; Rokka, J.; Eriksson, J.; Syvanen, S. ${ }^{11}$ C-PIB and ${ }^{124}$ I-antibody PET provide differing estimates of brain amyloid-beta after therapeutic intervention. J. Nucl. Med. 2021, 62. [CrossRef]

56. Brendel, M.; Jaworska, A.; Herms, J.; Trambauer, J.; Rötzer, C.; Gildehaus, F.J.; Carlsen, J.; Cumming, P.; Bylund, J.; Luebbers, T.; et al. Amyloid-PET predicts inhibition of de novo plaque formation upon chronic $\gamma$-secretase modulator treatment. Mol. Psychiatry 2015, 20, 1179-1187. [CrossRef] [PubMed]

57. Brendel, M.; Jaworska, A.; Overhoff, F.; Blume, T.; Probst, F.; Gildehaus, F.J.; Bartenstein, P.; Haass, C.; Bohrmann, B.; Herms, J.; et al. Efficacy of chronic BACE1 inhibition in PS2APP mice depends on the regional A $\beta$ deposition rate and plaque burden at treatment initiation. Theranostics 2018, 8, 4957-4968. [CrossRef]

58. Deleye, S.; Waldron, A.M.; Verhaeghe, J.; Bottelbergs, A.; Wyffels, L.; Van Broeck, B.; Langlois, X.; Schmidt, M.; Stroobants, S.; Staelens, S. Evaluation of Small-Animal PET Outcome Measures to Detect Disease Modification Induced by BACE Inhibition in a Transgenic Mouse Model of Alzheimer Disease. J. Nucl. Med. 2017, 58, 1977-1983. [CrossRef]

59. Xu, Y.; Wang, C.; Wey, H.-Y.; Liang, Y.; Chen, Z.; Choi, S.H.; Ran, C.; Rynearson, K.D.; Bernales, D.R.; Koegel, R.E.; et al. Molecular imaging of Alzheimer's disease-related gamma-secretase in mice and nonhuman primates. J. Exp. Med. 2020, 217, e20182266. [CrossRef]

60. Toyama, H.; Ye, D.; Ichise, M.; Liow, J.S.; Cai, L.; Jacobowitz, D.; Musachio, J.L.; Hong, J.; Crescenzo, M.; Tipre, D.; et al. PET imaging of brain with the beta-amyloid probe, $\left[{ }^{11} \mathrm{C}\right] 6-\mathrm{OH}-\mathrm{BTA}-1$, in a transgenic mouse model of Alzheimer's disease. Eur. J. Nucl. Med. Mol. Imaging 2005, 32, 593-600. [CrossRef]

61. Rojas, S.; Herance, J.R.; Gispert, J.D.; Abad, S.; Torrent, E.; Jiménez, X.; Pareto, D.; Perpiña, U.; Sarroca, S.; Rodríguez, E.; et al. In vivo evaluation of amyloid deposition and brain glucose metabolism of 5XFAD mice using positron emission tomography. Neurobiol. Aging 2013, 34, 1790-1798. [CrossRef]

62. Klunk, W.E.; Lopresti, B.J.; Ikonomovic, M.D.; Lefterov, I.M.; Koldamova, R.P.; Abrahamson, E.E.; Debnath, M.L.; Holt, D.P.; Huang, G.F.; Shao, L.; et al. Binding of the positron emission tomography tracer Pittsburgh compound-B reflects the amount of amyloid-beta in Alzheimer's disease brain but not in transgenic mouse brain. J. Neurosci. 2005, 25, 10598-10606. [CrossRef] [PubMed]

63. Manook, A.; Yousefi, B.H.; Willuweit, A.; Platzer, S.; Reder, S.; Voss, A.; Huisman, M.; Settles, M.; Neff, F.; Velden, J.; et al. Small-animal PET imaging of amyloid-beta plaques with $\left[{ }^{11} \mathrm{C}\right] \mathrm{PiB}$ and its multi-modal validation in an APP/PS1 mouse model of Alzheimer's disease. PLoS ONE 2012, 7, e31310. [CrossRef] [PubMed]

64. Maier, F.C.; Wehrl, H.F.; Schmid, A.M.; Mannheim, J.G.; Wiehr, S.; Lerdkrai, C.; Calaminus, C.; Stahlschmidt, A.; Ye, L.; Burnet, M.; et al. Longitudinal PET-MRI reveals $\beta$-amyloid deposition and rCBF dynamics and connects vascular amyloidosis to quantitative loss of perfusion. Nat. Med. 2014, 20, 1485-1492. [CrossRef] [PubMed]

65. von Reutern, B.; Grünecker, B.; Yousefi, B.H.; Henriksen, G.; Czisch, M.; Drzezga, A. Voxel-based analysis of amyloid-burden measured with $\left[{ }^{11} \mathrm{C}\right] \mathrm{PiB}$ PET in a double transgenic mouse model of Alzheimer's disease. Mol. Imaging Biol. 2013, 15, 576-584. [CrossRef] [PubMed]

66. Waldron, A.M.; Wintmolders, C.; Bottelbergs, A.; Kelley, J.B.; Schmidt, M.E.; Stroobants, S.; Langlois, X.; Staelens, S. In vivo molecular neuroimaging of glucose utilization and its association with fibrillar amyloid- $\beta$ load in aged APPPS1-21 mice. Alzheimers Res. Ther. 2015, 7, 76. [CrossRef]

67. Chiquita, S.; Ribeiro, M.; Castelhano, J.; Oliveira, F.; Sereno, J.; Batista, M.; Abrunhosa, A.; Rodrigues-Neves, A.C.; Carecho, R.; Baptista, F.; et al. A longitudinal multimodal in vivo molecular imaging study of the 3xTg-AD mouse model shows progressive early hippocampal and taurine loss. Hum. Mol. Genet. 2019, 28, 2174-2188. [CrossRef] [PubMed] 
68. Maeda, J.; Ji, B.; Irie, T.; Tomiyama, T.; Maruyama, M.; Okauchi, T.; Staufenbiel, M.; Iwata, N.; Ono, M.; Saido, T.C.; et al. Longitudinal, quantitative assessment of amyloid, neuroinflammation, and anti-amyloid treatment in a living mouse model of Alzheimer's disease enabled by positron emission tomography. J. Neurosci. 2007, 27, 10957-10968. [CrossRef]

69. Nishiyama, S.; Ohba, H.; Kanazawa, M.; Kakiuchi, T.; Tsukada, H. Comparing $\alpha 7$ nicotinic acetylcholine receptor binding, amyloid- $\beta$ deposition, and mitochondria complex-I function in living brain: A PET study in aged monkeys. Synapse 2015, 69, 475-483. [CrossRef]

70. Tsukada, H.; Nishiyama, S.; Ohba, H.; Kanazawa, M.; Kakiuchi, T.; Harada, N. Comparing amyloid- $\beta$ deposition, neuroinflammation, glucose metabolism, and mitochondrial complex I activity in brain: A PET study in aged monkeys. Eur. J. Nucl. Med. Mol. Imaging 2014, 41, 2127-2136. [CrossRef]

71. Frost, G.R.; Longo, V.; Li, T.; Jonas, L.A.; Judenhofer, M.; Cherry, S.; Koutcher, J.; Lekaye, C.; Zanzonico, P.; Li, Y.-M. Hybrid $\mathrm{PET} / \mathrm{MRI}$ enables high-spatial resolution, quantitative imaging of amyloid plaques in an Alzheimer's disease mouse model. Sci. Rep. 2020, 10, 10379. [CrossRef]

72. Waldron, A.M.; Wyffels, L.; Verhaeghe, J.; Richardson, J.C.; Schmidt, M.; Stroobants, S.; Langlois, X.; Staelens, S. Longitudinal Characterization of $\left[{ }^{18} \mathrm{~F}\right]-F D G$ and $\left[{ }^{18} \mathrm{~F}\right]-A V 45$ Uptake in the Double Transgenic TASTPM Mouse Model. J. Alzheimers Dis. 2017, 55, 1537-1548. [CrossRef] [PubMed]

73. Poisnel, G.; Dhilly, M.; Moustié, O.; Delamare, J.; Abbas, A.; Guilloteau, D.; Barré, L. PET imaging with [ ${ }^{18}$ F]AV-45 in an APP/PS1-21 murine model of amyloid plaque deposition. Neurobiol. Aging 2012, 33, 2561-2571. [CrossRef]

74. Sacher, C.; Blume, T.; Beyer, L.; Biechele, G.; Sauerbeck, J.; Eckenweber, F.; Deussing, M.; Focke, C.; Parhizkar, S.; Lindner, S.; et al. Asymmetry of fibrillar plaque burden in amyloid mouse models. J. Nucl. Med. 2020, 61, 1825-1831. [CrossRef]

75. Rominger, A.; Brendel, M.; Burgold, S.; Keppler, K.; Baumann, K.; Xiong, G.; Mille, E.; Gildehaus, F.J.; Carlsen, J.; Schlichtiger, J.; et al. Longitudinal assessment of cerebral $\beta$-amyloid deposition in mice overexpressing Swedish mutant $\beta$-amyloid precursor protein using ${ }^{18}$ F-florbetaben PET. J. Nucl. Med. 2013, 54, 1127-1134. [CrossRef] [PubMed]

76. Sacher, C.; Blume, T.; Beyer, L.; Peters, F.; Eckenweber, F.; Sgobio, C.; Deussing, M.; Albert, N.L.; Unterrainer, M.; Lindner, S.; et al. Longitudinal PET Monitoring of Amyloidosis and Microglial Activation in a Second-Generation Amyloid- $\beta$ Mouse Model. J. Nucl. Med. 2019, 60, 1787-1793. [CrossRef] [PubMed]

77. Biechele, G.; Wind, K.; Blume, T.; Sacher, C.; Beyer, L.; Eckenweber, F.; Franzmeier, N.; Ewers, M.; Zott, B.; Lindner, S.; et al. Microglial activation in the right amygdala-entorhinal-hippocampal complex is associated with preserved spatial learning in App(NL-G-F) mice. Neuroimage 2021, 230, 117707. [CrossRef] [PubMed]

78. Biechele, G.; Franzmeier, N.; Blume, T.; Ewers, M.; Luque, J.M.; Eckenweber, F.; Sacher, C.; Beyer, L.; Ruch-Rubinstein, F.; Lindner, S.; et al. Glial activation is moderated by sex in response to amyloidosis but not to tau pathology in mouse models of neurodegenerative diseases. J. Neuroinflamm. 2020, 17, 374. [CrossRef] [PubMed]

79. Blume, T.; Focke, C.; Peters, F.; Deussing, M.; Albert, N.L.; Lindner, S.; Gildehaus, F.-J.; von Ungern-Sternberg, B.; Ozmen, L.; Baumann, K.; et al. Microglial response to increasing amyloid load saturates with aging: A longitudinal dual tracer in vivo $\mu$ PET-study. J. Neuroinflamm. 2018, 15, 307. [CrossRef] [PubMed]

80. Chaney, A.M.; Lopez-Picon, F.R.; Serrière, S.; Wang, R.; Bochicchio, D.; Webb, S.D.; Vandesquille, M.; Harte, M.K.; Georgiadou, C.; Lawrence, $\mathrm{C}$; et al. Prodromal neuroinflammatory, cholinergic and metabolite dysfunction detected by PET and MRS in the TgF344-AD transgenic rat model of AD: A collaborative multi-modal study. Theranostics 2021, 11, 6644-6667. [CrossRef]

81. Franke, T.N.; Irwin, C.; Bayer, T.A.; Brenner, W.; Beindorff, N.; Bouter, C.; Bouter, Y. In vivo Imaging With ${ }^{18} \mathrm{~F}-\mathrm{FDG}-$ and ${ }^{18} \mathrm{~F}-$ Florbetaben-PET/MRI Detects Pathological Changes in the Brain of the Commonly Used 5XFAD Mouse Model of Alzheimer's Disease. Front. Med. 2020, 7, 529. [CrossRef]

82. Rodriguez-Vieitez, E.; Ni, R.; Gulyas, B.; Toth, M.; Haggkvist, J.; Halldin, C.; Voytenko, L.; Marutle, A.; Nordberg, A. Astrocytosis precedes amyloid plaque deposition in Alzheimer APPswe transgenic mouse brain: A correlative positron emission tomography and in vitro imaging study. Eur. J. Nucl. Med. Mol. Imaging 2015, 42, 1119-1132. [CrossRef]

83. Johnson, A.E.; Jeppsson, F.; Sandell, J.; Wensbo, D.; Neelissen, J.A.; Juréus, A.; Ström, P.; Norman, H.; Farde, L.; Svensson, S.P. AZD2184: A radioligand for sensitive detection of beta-amyloid deposits. J. Neurochem. 2009, 108, 1177-1186. [CrossRef]

84. Kudo, Y.; Okamura, N.; Furumoto, S.; Tashiro, M.; Furukawa, K.; Maruyama, M.; Itoh, M.; Iwata, R.; Yanai, K.; Arai, H. 2-(2-[2Dimethylaminothiazol-5-yl]ethenyl)-6- (2-[fluoro]ethoxy)benzoxazole: A novel PET agent for in vivo detection of dense amyloid plaques in Alzheimer's disease patients. J. Nucl. Med. 2007, 48, 553-561. [CrossRef]

85. Furumoto, S.; Okamura, N.; Furukawa, K.; Tashiro, M.; Ishikawa, Y.; Sugi, K.; Tomita, N.; Waragai, M.; Harada, R.; Tago, T.; et al. A ${ }^{18}$ F-Labeled BF-227 Derivative as a Potential Radioligand for Imaging Dense Amyloid Plaques by Positron Emission Tomography. Mol. Imaging Biol. 2013, 15, 497-506. [CrossRef] [PubMed]

86. Sundaram, G.S.M.; Dhavale, D.D.; Prior, J.L.; Yan, P.; Cirrito, J.; Rath, N.P.; Laforest, R.; Cairns, N.J.; Lee, J.-M.; Kotzbauer, P.T.; et al. Fluselenamyl: A Novel Benzoselenazole Derivative for PET Detection of Amyloid Plaques (A $\beta$ ) in Alzheimer's Disease. Sci. Rep. 2016, 6, 35636. [CrossRef] [PubMed]

87. Sehlin, D.; Fang, X.T.; Cato, L.; Antoni, G.; Lannfelt, L.; Syvanen, S. Antibody-based PET imaging of amyloid beta in mouse models of Alzheimer's disease. Nat. Commun. 2016, 7, 10759. [CrossRef]

88. Liu, Y.; Yang, Y.; Sun, M.; Cui, M.; Fu, Y.; Lin, Y.; Li, Z.; Nie, L. Highly specific noninvasive photoacoustic and positron emission tomography of brain plaque with functionalized croconium dye labeled by a radiotracer. Chem. Sci. 2017, 8, 2710-2716. [CrossRef] [PubMed] 
89. An, Y.; Varma, V.R.; Varma, S.; Casanova, R.; Dammer, E.; Pletnikova, O.; Chia, C.W.; Egan, J.M.; Ferrucci, L.; Troncoso, J.; et al. Evidence for brain glucose dysregulation in Alzheimer's disease. Alzheimer Dement. 2018, 14, 318-329. [CrossRef] [PubMed]

90. Foster, N.L.; Heidebrink, J.L.; Clark, C.M.; Jagust, W.J.; Arnold, S.E.; Barbas, N.R.; DeCarli, C.S.; Turner, R.S.; Koeppe, R.A.; Higdon, R.; et al. FDG-PET improves accuracy in distinguishing frontotemporal dementia and Alzheimer's disease. Brain 2007, 130, 2616-2635. [CrossRef]

91. Bouter, C.; Henniges, P.; Franke, T.N.; Irwin, C.; Sahlmann, C.O.; Sichler, M.E.; Beindorff, N.; Bayer, T.A.; Bouter, Y. ${ }^{18}$ F-FDG-PET Detects Drastic Changes in Brain Metabolism in the Tg4-42 Model of Alzheimer's Disease. Front. Aging Neurosci. 2018, 10, 425. [CrossRef]

92. Kuntner, C.; Kesner, A.L.; Bauer, M.; Kremslehner, R.; Wanek, T.; Mandler, M.; Karch, R.; Stanek, J.; Wolf, T.; Müller, M.; et al. Limitations of small animal PET imaging with $\left[{ }^{18}\right.$ F]FDDNP and FDG for quantitative studies in a transgenic mouse model of Alzheimer's disease. Mol. Imaging Biol. 2009, 11, 236-240. [CrossRef] [PubMed]

93. Belfiore, R.; Rodin, A.; Ferreira, E.; Velazquez, R.; Branca, C.; Caccamo, A.; Oddo, S. Temporal and regional progression of Alzheimer's disease-like pathology in 3xTg-AD mice. Aging Cell 2019, 18, e12873. [CrossRef] [PubMed]

94. Adlimoghaddam, A.; Snow, W.M.; Stortz, G.; Perez, C.; Djordjevic, J.; Goertzen, A.L.; Ko, J.H.; Albensi, B.C. Regional hypometabolism in the 3xTg mouse model of Alzheimer's disease. Neurobiol. Dis. 2019, 127, 264-277. [CrossRef]

95. Bouter, C.; Bouter, Y. ${ }^{18}$ F-FDG-PET in Mouse Models of Alzheimer's Disease. Front. Med. 2019, 6, 71. [CrossRef] [PubMed]

96. Snellman, A.; Takkinen, J.S.; López-Picón, F.R.; Eskola, O.; Solin, O.; Rinne, J.O.; Haaparanta-Solin, M. Effect of genotype and age on cerebral $\left[{ }^{18} \mathrm{~F}\right] \mathrm{FDG}$ uptake varies between transgenic APPSwe-PS1dE9 and Tg2576 mouse models of Alzheimer's disease. Sci. Rep. 2019, 9, 5700. [CrossRef] [PubMed]

97. Xiang, X.; Wind, K.; Wiedemann, T.; Blume, T.; Shi, Y.; Briel, N.; Beyer, L.; Biechele, G.; Eckenweber, F.; Zatcepin, A.; et al. Microglial activation states drive glucose uptake and FDG-PET alterations in neurodegenerative diseases. Sci. Transl. Med. 2021, 13, eabe5640. [CrossRef] [PubMed]

98. Nicholson, R.M.; Kusne, Y.; Nowak, L.A.; LaFerla, F.M.; Reiman, E.M.; Valla, J. Regional cerebral glucose uptake in the 3xTG model of Alzheimer's disease highlights common regional vulnerability across AD mouse models. Brain Res. 2010, 1347, 179-185. [CrossRef] [PubMed]

99. Sancheti, H.; Akopian, G.; Yin, F.; Brinton, R.D.; Walsh, J.P.; Cadenas, E. Age-dependent modulation of synaptic plasticity and insulin mimetic effect of lipoic acid on a mouse model of Alzheimer's disease. PLoS ONE 2013, 8, e69830. [CrossRef]

100. Luo, F.; Rustay, N.R.; Ebert, U.; Hradil, V.P.; Cole, T.B.; Llano, D.A.; Mudd, S.R.; Zhang, Y.; Fox, G.B.; Day, M. Characterization of 7- and 19-month-old Tg2576 mice using multimodal in vivo imaging: Limitations as a translatable model of Alzheimer's disease. Neurobiol. Aging 2012, 33, 933-944. [CrossRef]

101. Lourenço, C.F.; Ledo, A.; Barbosa, R.M.; Laranjinha, J. Neurovascular uncoupling in the triple transgenic model of Alzheimer's disease: Impaired cerebral blood flow response to neuronal-derived nitric oxide signaling. Exp. Neurol. 2017, 291, 36-43. [CrossRef]

102. Liu, Y.; Xu, Y.; Li, M.; Pan, D.; Li, Y.; Wang, Y.; Wang, L.; Wu, Q.; Yang, M. Multi-target PET evaluation in APP/PS1/tau mouse model of Alzheimer's disease. Neurosci. Lett. 2020, 728, 134938. [CrossRef] [PubMed]

103. Xu, A.; Zeng, Q.; Tang, Y.; Wang, X.; Yuan, X.; Zhou, Y.; Li, Z. Electroacupuncture Protects Cognition by Regulating Tau Phosphorylation and Glucose Metabolism via the AKT/GSK3 $\beta$ Signaling Pathway in Alzheimer's Disease Model Mice. Front. Neurosci. 2020, 14, 585476. [CrossRef] [PubMed]

104. Poisnel, G.; Hérard, A.S.; El Tannir El Tayara, N.; Bourrin, E.; Volk, A.; Kober, F.; Delatour, B.; Delzescaux, T.; Debeir, T.; Rooney, T.; et al. Increased regional cerebral glucose uptake in an APP/PS1 model of Alzheimer's disease. Neurobiol. Aging 2012, 33, 1995-2005. [CrossRef] [PubMed]

105. Takkinen, J.S.; López-Picón, F.R.; Al Majidi, R.; Eskola, O.; Krzyczmonik, A.; Keller, T.; Löyttyniemi, E.; Solin, O.; Rinne, J.O.; Haaparanta-Solin, M. Brain energy metabolism and neuroinflammation in ageing APP/PS1-21 mice using longitudinal ${ }^{18}$ F-FDG and ${ }^{18}$ F-DPA-714 PET imaging. J. Cereb. Blood Flow Metab. 2017, 37, 2870-2882. [CrossRef]

106. Stojakovic, A.; Trushin, S.; Sheu, A.; Khalili, L.; Chang, S.Y.; Li, X.; Christensen, T.; Salisbury, J.L.; Geroux, R.E.; Gateno, B.; et al. Partial inhibition of mitochondrial complex I ameliorates Alzheimer's disease pathology and cognition in APP/PS1 female mice. Commun. Biol. 2021, 4, 61. [CrossRef]

107. Wagner, J.M.; Sichler, M.E.; Schleicher, E.M.; Franke, T.N.; Irwin, C.; Löw, M.J.; Beindorff, N.; Bouter, C.; Bayer, T.A.; Bouter, Y. Analysis of Motor Function in the Tg4-42 Mouse Model of Alzheimer's Disease. Front. Behav. Neurosci. 2019, 13, 107. [CrossRef]

108. Macdonald, I.R.; DeBay, D.R.; Reid, G.A.; O'Leary, T.P.; Jollymore, C.T.; Mawko, G.; Burrell, S.; Martin, E.; Bowen, C.V.; Brown, R.E.; et al. Early detection of cerebral glucose uptake changes in the 5XFAD mouse. Curr. Alzheimer Res. 2014, 11, 450-460. [CrossRef]

109. Choi, H.; Choi, Y.; Lee, E.J.; Kim, H.; Lee, Y.; Kwon, S.; Hwang, D.W.; Lee, D.S. Hippocampal glucose uptake as a surrogate of metabolic change of microglia in Alzheimer's disease. J. Neuroinflamm. 2021, 18, 190. [CrossRef]

110. Teng, E.; Kepe, V.; Frautschy, S.A.; Liu, J.; Satyamurthy, N.; Yang, F.; Chen, P.P.; Cole, G.B.; Jones, M.R.; Huang, S.C.; et al. [F-18]FDDNP microPET imaging correlates with brain A $\beta$ burden in a transgenic rat model of Alzheimer disease: Effects of aging, in vivo blockade, and anti-A $\beta$ antibody treatment. Neurobiol. Dis. 2011, 43, 565-575. [CrossRef] 
111. Winkeler, A.; Waerzeggers, Y.; Klose, A.; Monfared, P.; Thomas, A.V.; Schubert, M.; Heneka, M.T.; Jacobs, A.H. Imaging noradrenergic influence on amyloid pathology in mouse models of Alzheimer's disease. Eur. J. Nucl. Med. Mol. Imaging 2008, 35, S107-S113. [CrossRef]

112. Deleye, S.; Waldron, A.M.; Richardson, J.C.; Schmidt, M.; Langlois, X.; Stroobants, S.; Staelens, S. The Effects of Physiological and Methodological Determinants on ${ }^{18}$ F-FDG Mouse Brain Imaging Exemplified in a Double Transgenic Alzheimer Model. Mol. Imaging 2016, 15. [CrossRef]

113. Toyonaga, T.; Smith, L.M.; Finnema, S.J.; Gallezot, J.D.; Naganawa, M.; Bini, J.; Mulnix, T.; Cai, Z.; Ropchan, J.; Huang, Y.; et al. In Vivo Synaptic Density Imaging with ${ }^{11}$ C-UCB-J Detects Treatment Effects of Saracatinib in a Mouse Model of Alzheimer Disease. J. Nucl. Med. 2019, 60, 1780-1786. [CrossRef]

114. Xiong, M.; Roshanbin, S.; Rokka, J.; Schlein, E.; Ingelsson, M.; Sehlin, D.; Eriksson, J.; Syvänen, S. In vivo imaging of synaptic density with [ ${ }^{11}$ C]UCB-J PET in two mouse models of neurodegenerative disease. NeuroImage 2021, 239, 118302. [CrossRef] [PubMed]

115. Sadasivam, P.; Fang, X.T.; Toyonaga, T.; Lee, S.; Xu, Y.; Zheng, M.Q.; Spurrier, J.; Huang, Y.; Strittmatter, S.M.; Carson, R.E.; et al. Quantification of SV2A Binding in Rodent Brain Using [ ${ }^{18}$ F]SynVesT-1 and PET Imaging. Mol. Imaging Biol. 2021, $23,372-381$. [CrossRef] [PubMed]

116. Lee, M.; Lee, H.J.; Jeong, Y.J.; Oh, S.J.; Kang, K.J.; Han, S.J.; Nam, K.R.; Lee, Y.J.; Lee, K.C.; Ryu, Y.H.; et al. Age dependency of mGluR5 availability in 5xFAD mice measured by PET. Neurobiol. Aging 2019, 84, 208-216. [CrossRef] [PubMed]

117. Son, Y.; Jeong, Y.J.; Shin, N.-R.; Oh, S.J.; Nam, K.R.; Choi, H.-D.; Choi, J.Y.; Lee, H.-J. Inhibition of Colony-Stimulating Factor 1 Receptor by PLX3397 Prevents Amyloid Beta Pathology and Rescues Dopaminergic Signaling in Aging 5xFAD Mice. Int. J. Mol. Sci. 2020, 21, 5553. [CrossRef] [PubMed]

118. Varlow, C.; Murrell, E.; Holland, J.P.; Kassenbrock, A.; Shannon, W.; Liang, S.H.; Vasdev, N.; Stephenson, N.A. Revisiting the Radiosynthesis of $\left[{ }^{18}\right.$ F]FPEB and Preliminary PET Imaging in a Mouse Model of Alzheimer's Disease. Molecules 2020, $25,982$. [CrossRef] [PubMed]

119. Fang, X.T.; Eriksson, J.; Antoni, G.; Yngve, U.; Cato, L.; Lannfelt, L.; Sehlin, D.; Syvänen, S. Brain mGluR5 in mice with amyloid beta pathology studied with in vivo [11 C]ABP688 PET imaging and ex vivo immunoblotting. Neuropharmacology 2017, 113, 293-300. [CrossRef] [PubMed]

120. Heneka, M.T.; Ramanathan, M.; Jacobs, A.H.; Dumitrescu-Ozimek, L.; Bilkei-Gorzo, A.; Debeir, T.; Sastre, M.; Galldiks, N.; Zimmer, A.; Hoehn, M.; et al. Locus ceruleus degeneration promotes Alzheimer pathogenesis in amyloid precursor protein 23 transgenic mice. J. Neurosci. 2006, 26, 1343-1354. [CrossRef]

121. Rejc, L.; Gómez-Vallejo, V.; Joya, A.; Moreno, O.; Egimendia, A.; Castellnou, P.; Ríos-Anglada, X.; Cossío, U.; Baz, Z.; Passannante, R.; et al. Longitudinal evaluation of a novel BChE PET tracer as an early in vivo biomarker in the brain of a mouse model for Alzheimer disease. Theranostics 2021, 11, 6542-6559. [CrossRef] [PubMed]

122. Chen, Y.A.; Lu, C.H.; Ke, C.C.; Chiu, S.J.; Chang, C.W.; Yang, B.H.; Gelovani, J.G.; Liu, R.S. Evaluation of Class IIa Histone Deacetylases Expression and In Vivo Epigenetic Imaging in a Transgenic Mouse Model of Alzheimer's Disease. Int. J. Mol. Sci. 2021, 22, 8633. [CrossRef] [PubMed]

123. Satoru, Y.; Yurika, I.; Shunsuke, I.; Takeharu, K.; Hiroyuki, O.; Shingo, N.; Masakatsu, K.; Hideo, T.; Kohji, S.; Yasuomi, O. In Vivo elevation of mitochondrial activity and amyloid deposition, but inversely correlated, in early-stage senescence-accelerated mice: A positron emission tomography study. Res. Sq. 2021. [CrossRef]

124. Terada, T.; Therriault, J.; Kang, M.S.P.; Savard, M.; Pascoal, T.A.; Lussier, F.; Tissot, C.; Wang, Y.-T.; Benedet, A.; Matsudaira, T.; et al. Mitochondrial complex I abnormalities is associated with tau and clinical symptoms in mild Alzheimer's disease. Mol. Neurodegener. 2021, 16, 28. [CrossRef] [PubMed]

125. Torres, J.B.; Andreozzi, E.M.; Dunn, J.T.; Siddique, M.; Szanda, I.; Howlett, D.R.; Sunassee, K.; Blower, P.J. PET Imaging of Copper Trafficking in a Mouse Model of Alzheimer Disease. J. Nucl. Med. 2016, 57, 109-114. [CrossRef] [PubMed]

126. Sai, K.S.; Damuka, N.; Mintz, A.; Whitlow, C.T.; Craft, S.; Macauley-Rambach, S. [ ${ }^{11}$ C]MPC-6827, a microtubule-based PET imaging tracer: A potential early imaging biomarker for AD and other ADRDs. Alzheimer's Dement. 2020, 16, e037790. [CrossRef]

127. Bernard-Gauthier, V.; Mossine, A.V.; Knight, A.; Patnaik, D.; Zhao, W.N.; Cheng, C.; Krishnan, H.S.; Xuan, L.L.; Chindavong, P.S.; Reis, S.A.; et al. Structural Basis for Achieving GSK-3 $\beta$ Inhibition with High Potency, Selectivity, and Brain Exposure for Positron Emission Tomography Imaging and Drug Discovery. J. Med. Chem. 2019, 62, 9600-9617. [CrossRef]

128. Giglio, J.; Fernandez, S.; Martinez, A.; Zeni, M.; Reyes, L.; Rey, A.; Cerecetto, H. Glycogen Synthase Kinase-3 Maleimide Inhibitors As Potential PET-Tracers for Imaging Alzheimer's Disease: ${ }^{11}$ C-Synthesis and In Vivo Proof of Concept. J. Med. Chem. 2021. [CrossRef]

129. Luzi, F.; Savickas, V.; Taddei, C.; Hader, S.; Singh, N.; Gee, A.D.; Bongarzone, S. Radiolabeling of [11C]FPS-ZM1, a receptor for advanced glycation end products-targeting positron emission tomography radiotracer, using a $\left[{ }^{11} \mathrm{C}\right] \mathrm{CO}(2)-$ to- $\left[{ }^{11} \mathrm{C}\right] \mathrm{CO}$ chemical conversion. Future Med. Chem. 2020, 12, 511-521. [CrossRef]

130. Zoufal, V.; Mairinger, S.; Krohn, M.; Wanek, T.; Filip, T.; Sauberer, M.; Stanek, J.; Kuntner, C.; Pahnke, J.; Langer, O. Measurement of cerebral ABCC1 transport activity in wild-type and APP/PS1-21 mice with positron emission tomography. J. Cereb. Blood Flow Metab. 2020, 40, 954-965. [CrossRef] 
131. Wanek, T.; Zoufal, V.; Brackhan, M.; Krohn, M.; Mairinger, S.; Filip, T.; Sauberer, M.; Stanek, J.; Pekar, T.; Pahnke, J.; et al. Brain Distribution of Dual ABCB1/ABCG2 Substrates Is Unaltered in a Beta-Amyloidosis Mouse Model. Int. J. Mol. Sci. 2020, $21,8245$. [CrossRef]

132. Zoufal, V.; Mairinger, S.; Brackhan, M.; Krohn, M.; Filip, T.; Sauberer, M.; Stanek, J.; Wanek, T.; Tournier, N.; Bauer, M.; et al. Imaging P-Glycoprotein Induction at the Blood-Brain Barrier of a $\beta$-Amyloidosis Mouse Model with ${ }^{11} \mathrm{C}-$ Metoclopramide PET. J. Nucl. Med. 2020, 61, 1050-1057. [CrossRef] [PubMed]

133. Zoufal, V.; Wanek, T.; Krohn, M.; Mairinger, S.; Filip, T.; Sauberer, M.; Stanek, J.; Pekar, T.; Bauer, M.; Pahnke, J.; et al. Age dependency of cerebral P-glycoprotein function in wild-type and APPPS1 mice measured with PET. J. Cereb. Blood Flow Metab. 2020, 40, 150-162. [CrossRef] [PubMed]

134. Brendel, M.; Probst, F.; Jaworska, A.; Overhoff, F.; Korzhova, V.; Albert, N.L.; Beck, R.; Lindner, S.; Gildehaus, F.J.; Baumann, K.; et al. Glial Activation and Glucose Metabolism in a Transgenic Amyloid Mouse Model: A Triple-Tracer PET Study. J. Nucl. Med. 2016, 57, 954-960. [CrossRef] [PubMed]

135. DeKosky, S.T.; Scheff, S.W. Synapse loss in frontal cortex biopsies in Alzheimer's disease: Correlation with cognitive severity. Ann. Neurol. 1990, 27, 457-464. [CrossRef] [PubMed]

136. Lynch, B.A.; Lambeng, N.; Nocka, K.; Kensel-Hammes, P.; Bajjalieh, S.M.; Matagne, A.; Fuks, B. The synaptic vesicle protein SV2A is the binding site for the antiepileptic drug levetiracetam. Proc. Natl. Acad. Sci. USA 2004, 101, 9861-9866. [CrossRef]

137. Heurling, K.; Ashton, N.J.; Leuzy, A.; Zimmer, E.R.; Blennow, K.; Zetterberg, H.; Eriksson, J.; Lubberink, M.; Schöll, M. Synaptic vesicle protein 2A as a potential biomarker in synaptopathies. Mol. Cell. Neurosci. 2019, 97, 34-42. [CrossRef]

138. Kong, Y.; Huang, L.; Li, W.; Liu, X.; Zhou, Y.; Liu, C.; Zhang, S.; Xie, F.; Zhang, Z.; Jiang, D.; et al. The Synaptic Vesicle Protein 2A Interacts With Key Pathogenic Factors in Alzheimer's Disease: Implications for Treatment. Front. Cell Dev. Biol. 2021, 9, 609908. [CrossRef]

139. Chen, M.K.; Mecca, A.P.; Naganawa, M.; Finnema, S.J.; Toyonaga, T.; Lin, S.F.; Najafzadeh, S.; Ropchan, J.; Lu, Y.; McDonald, J.W.; et al. Assessing Synaptic Density in Alzheimer Disease With Synaptic Vesicle Glycoprotein 2A Positron Emission Tomographic Imaging. JAMA Neurol. 2018, 75, 1215-1224. [CrossRef]

140. Finnema, S.J.; Nabulsi, N.B.; Eid, T.; Detyniecki, K.; Lin, S.F.; Chen, M.K.; Dhaher, R.; Matuskey, D.; Baum, E.; Holden, D.; et al. Imaging synaptic density in the living human brain. Sci. Transl. Med. 2016, 8, 348ra396. [CrossRef]

141. Nowack, A.; Malarkey, E.B.; Yao, J.; Bleckert, A.; Hill, J.; Bajjalieh, S.M. Levetiracetam reverses synaptic deficits produced by overexpression of SV2A. PLoS ONE 2011, 6, e29560. [CrossRef]

142. Bahri, M.A.; Plenevaux, A.; Aerts, J.; Bastin, C.; Becker, G.; Mercier, J.; Valade, A.; Buchanan, T.; Mestdagh, N.; Ledoux, D.; et al. Measuring brain synaptic vesicle protein $2 \mathrm{~A}$ with positron emission tomography and $\left[{ }^{18} \mathrm{~F}\right] \mathrm{UCB}-\mathrm{H}$. Alzheimer's Dement. 2017, 3, 481-486. [CrossRef] [PubMed]

143. Naganawa, M.; Li, S.; Nabulsi, N.; Henry, S.; Zheng, M.Q.; Pracitto, R.; Cai, Z.; Gao, H.; Kapinos, M.; Labaree, D.; et al. First-inHuman Evaluation of ${ }^{18}$ F-SynVesT-1, a Radioligand for PET Imaging of Synaptic Vesicle Glycoprotein 2A. J. Nucl. Med. 2021, 62, 561-567. [CrossRef] [PubMed]

144. Li, S.; Cai, Z.; Wu, X.; Holden, D.; Pracitto, R.; Kapinos, M.; Gao, H.; Labaree, D.; Nabulsi, N.; Carson, R.E.; et al. Synthesis and in Vivo Evaluation of a Novel PET Radiotracer for Imaging of Synaptic Vesicle Glycoprotein 2A (SV2A) in Nonhuman Primates. ACS Chem. Neurosci. 2019, 10, 1544-1554. [CrossRef] [PubMed]

145. Constantinescu, C.C.; Tresse, C.; Zheng, M.; Gouasmat, A.; Carroll, V.M.; Mistico, L.; Alagille, D.; Sandiego, C.M.; Papin, C.; Marek, K.; et al. Development and In Vivo Preclinical Imaging of Fluorine-18-Labeled Synaptic Vesicle Protein 2A (SV2A) PET Tracers. Mol. Imaging Biol. 2019, 21, 509-518. [CrossRef]

146. O'Dell, R.S.; Mecca, A.P.; Chen, M.-K.; Naganawa, M.; Toyonaga, T.; Lu, Y.; Godek, T.A.; Harris, J.E.; Bartlett, H.H.; Banks, E.R.; et al. Association of $A \beta$ deposition and regional synaptic density in early Alzheimer's disease: A PET imaging study with $\left[{ }^{11} \mathrm{C}\right] \mathrm{UCB}-\mathrm{J}$. Alzheimer Res. Ther. 2021, 13, 11. [CrossRef]

147. Bertoglio, D.; Verhaeghe, J.; Miranda, A.; Kertesz, I.; Cybulska, K.; Korat, Š.; Wyffels, L.; Stroobants, S.; Mrzljak, L.; Liu, L.; et al. Validation and noninvasive kinetic modeling of $\left[{ }^{11}\right.$ C $]$ UCB-J PET imaging in mice. J. Cereb. Blood Flow Metab. 2019, 40, 0271678X1986408. [CrossRef]

148. Cai, Z.; Li, S.; Zhang, W.; Pracitto, R.; Wu, X.; Baum, E.; Finnema, S.J.; Holden, D.; Toyonaga, T.; Lin, S.-f.; et al. Synthesis and Preclinical Evaluation of an ${ }^{18}$ F-Labeled Synaptic Vesicle Glycoprotein 2A PET Imaging Probe: $\left[{ }^{18}\right.$ F $]$ SynVesT-2. ACS Chem. Neurosci. 2020, 11, 592-603. [CrossRef]

149. Iacobucci, G.J.; Popescu, G.K. NMDA receptors: Linking physiological output to biophysical operation. Nat. Rev. Neurosci. 2017, 18, 236-249. [CrossRef]

150. Nedergaard, M.; Takano, T.; Hansen, A.J. Beyond the role of glutamate as a neurotransmitter. Nat. Rev. Neurosci. 2002, 3, 748-755. [CrossRef]

151. Palop, J.J.; Mucke, L. Network abnormalities and interneuron dysfunction in Alzheimer disease. Nat. Rev. Neurosci. 2016, 17, 777-792. [CrossRef]

152. Wang, R.; Reddy, P.H. Role of Glutamate and NMDA Receptors in Alzheimer's Disease. J. Alzheimers Dis. 2017, 57, 1041-1048. [CrossRef] [PubMed]

153. Tanzi, R.E. The synaptic Abeta hypothesis of Alzheimer disease. Nat. Neurosci. 2005, 8, 977-979. [CrossRef] [PubMed] 
154. Snyder, E.M.; Nong, Y.; Almeida, C.G.; Paul, S.; Moran, T.; Choi, E.Y.; Nairn, A.C.; Salter, M.W.; Lombroso, P.J.; Gouras, G.K.; et al. Regulation of NMDA receptor trafficking by amyloid-beta. Nat. Neurosci. 2005, 8, 1051-1058. [CrossRef] [PubMed]

155. Shankar, G.M.; Bloodgood, B.L.; Townsend, M.; Walsh, D.M.; Selkoe, D.J.; Sabatini, B.L. Natural oligomers of the Alzheimer amyloid-beta protein induce reversible synapse loss by modulating an NMDA-type glutamate receptor-dependent signaling pathway. J. Neurosci. 2007, 27, 2866-2875. [CrossRef] [PubMed]

156. Um, J.W.; Kaufman, A.C.; Kostylev, M.; Heiss, J.K.; Stagi, M.; Takahashi, H.; Kerrisk, M.E.; Vortmeyer, A.; Wisniewski, T. Metabotropic Glutamate Receptor 5 Is a Coreceptor for Alzheimer A $\beta$ Oligomer Bound to Cellular Prion Protein. Neuron 2013, 79, 887-902. [CrossRef]

157. Reinders, N.R.; Pao, Y.; Renner, M.C.; da Silva-Matos, C.M.; Lodder, T.R.; Malinow, R.; Kessels, H.W. Amyloid- $\beta$ effects on synapses and memory require AMPA receptor subunit GluA3. Proc. Natl. Acad. Sci. USA 2016, 113, E6526-E6534. [CrossRef] [PubMed]

158. Tanaka, H.; Sakaguchi, D.; Hirano, T. Amyloid- $\beta$ oligomers suppress subunit-specific glutamate receptor increase during LTP. Alzheimers Dement. 2019, 5, 797-808. [CrossRef] [PubMed]

159. Zott, B.; Simon, M.M.; Hong, W.; Unger, F.; Chen-Engerer, H.J.; Frosch, M.P.; Sakmann, B.; Walsh, D.M.; Konnerth, A. A vicious cycle of $\beta$ amyloid-dependent neuronal hyperactivation. Science 2019, 365, 559-565. [CrossRef]

160. Hamilton, A.; Vasefi, M.; Vander Tuin, C.; McQuaid, R.J.; Anisman, H.; Ferguson, S.S. Chronic Pharmacological mGluR5 Inhibition Prevents Cognitive Impairment and Reduces Pathogenesis in an Alzheimer Disease Mouse Model. Cell Rep. 2016, 15, 1859-1865. [CrossRef]

161. Miyazaki, T.; Nakajima, W.; Hatano, M.; Shibata, Y.; Kuroki, Y.; Arisawa, T.; Serizawa, A.; Sano, A.; Kogami, S.; Yamanoue, T.; et al. Visualization of AMPA receptors in living human brain with positron emission tomography. Nat. Med. 2020, 26, 281-288. [CrossRef]

162. Takahata, K.; Kimura, Y.; Seki, C.; Tokunaga, M.; Ichise, M.; Kawamura, K.; Ono, M.; Kitamura, S.; Kubota, M.; Moriguchi, S.; et al. A human PET study of [ $\left.{ }^{11} \mathrm{C}\right]$ HMS011, a potential radioligand for AMPA receptors. EJNMMI Res. 2017, 7, 63. [CrossRef] [PubMed]

163. Vibholm, A.K.; Landau, A.M.; Møller, A.; Jacobsen, J.; Vang, K.; Munk, O.L.; Orlowski, D.; Sørensen, J.C.; Brooks, D.J. NMDA receptor ion channel activation detected in vivo with $\left[{ }^{18} \mathrm{~F}\right] \mathrm{GE}-179 \mathrm{PET}$ after electrical stimulation of rat hippocampus. J. Cereb. Blood Flow Metab. 2021, 41, 1301-1312. [CrossRef] [PubMed]

164. van der Aart, J.; Golla, S.S.V.; van der Pluijm, M.; Schwarte, L.A.; Schuit, R.C.; Klein, P.J.; Metaxas, A.; Windhorst, A.D.; Boellaard, R.; Lammertsma, A.A.; et al. First in human evaluation of $\left[{ }^{18} \mathrm{~F}\right] \mathrm{PK}-209$, a PET ligand for the ion channel binding site of NMDA receptors. EJNMMI Res. 2018, 8, 69. [CrossRef] [PubMed]

165. Krämer, S.D.; Betzel, T.; Mu, L.; Haider, A.; Herde, A.M.; Boninsegni, A.K.; Keller, C.; Szermerski, M.; Schibli, R.; Wünsch, B.; et al. Evaluation of ${ }^{11} \mathrm{C}-\mathrm{Me}-\mathrm{NB} 1$ as a Potential PET Radioligand for Measuring GluN2B-Containing NMDA Receptors, Drug Occupancy, and Receptor Cross Talk. J. Nucl. Med. 2018, 59, 698-703. [CrossRef]

166. Abd-Elrahman, K.S.; Albaker, A.; de Souza, J.M.; Ribeiro, F.M.; Schlossmacher, M.G.; Tiberi, M.; Hamilton, A.; Ferguson, S.S.G A $\beta$ oligomers induce pathophysiological mGluR5 signaling in Alzheimer's disease model mice in a sex-selective manner. Sci. Signal 2020, 13. [CrossRef] [PubMed]

167. Wong, D.F.; Waterhouse, R.; Kuwabara, H.; Kim, J.; Brašić, J.R.; Chamroonrat, W.; Stabins, M.; Holt, D.P.; Dannals, R.F.; Hamill, T.G.; et al. ${ }^{18}$ F-FPEB, a PET radiopharmaceutical for quantifying metabotropic glutamate 5 receptors: A first-in-human study of radiochemical safety, biokinetics, and radiation dosimetry. J. Nucl. Med. 2013, 54, 388-396. [CrossRef] [PubMed]

168. Ametamey, S.M.; Kessler, L.J.; Honer, M.; Wyss, M.T.; Buck, A.; Hintermann, S.; Auberson, Y.P.; Gasparini, F.; Schubiger, P.A. Radiosynthesis and preclinical evaluation of ${ }^{11} \mathrm{C}-\mathrm{ABP} 688$ as a probe for imaging the metabotropic glutamate receptor subtype 5 . J. Nucl. Med. 2006, 47, 698-705. [PubMed]

169. Warnock, G.; Sommerauer, M.; Mu, L.; Pla Gonzalez, G.; Geistlich, S.; Treyer, V.; Schibli, R.; Buck, A.; Krämer, S.D.; Ametamey, S.M. A first-in-man PET study of $\left[{ }^{18} \mathrm{~F}\right] \mathrm{PSS} 232$, a fluorinated ABP688 derivative for imaging metabotropic glutamate receptor subtype 5. Eur. J. Nucl. Med. Mol. Imaging 2018, 45, 1041-1051. [CrossRef]

170. Mecca, A.P.; McDonald, J.W.; Michalak, H.R.; Godek, T.A.; Harris, J.E.; Pugh, E.A.; Kemp, E.C.; Chen, M.K.; Salardini, A.; Nabulsi, N.B.; et al. PET imaging of mGluR5 in Alzheimer's disease. Alzheimers Res. Ther. 2020, 12, 15. [CrossRef]

171. Treyer, V.; Gietl, A.F.; Suliman, H.; Gruber, E.; Meyer, R.; Buchmann, A.; Johayem, A.; Unschuld, P.G.; Nitsch, R.M.; Buck, A.; et al. Reduced uptake of $\left[{ }^{11} \mathrm{C}\right]-\mathrm{ABP} 688$, a PET tracer for metabolic glutamate receptor 5 in hippocampus and amygdala in Alzheimer's dementia. Brain Behav. 2020, 10, e01632. [CrossRef]

172. Nordberg, A. Nicotinic receptor abnormalities of Alzheimer's disease: Therapeutic implications. Biol. Psychiatry 2001, 49, 200-210. [CrossRef]

173. Hampel, H.; Mesulam, M.M.; Cuello, A.C.; Farlow, M.R.; Giacobini, E.; Grossberg, G.T.; Khachaturian, A.S.; Vergallo, A.; Cavedo, E.; Snyder, P.J.; et al. The cholinergic system in the pathophysiology and treatment of Alzheimer's disease. Brain 2018, 141, 1917-1933. [CrossRef] [PubMed]

174. Wang, H.; Yu, M.; Ochani, M.; Amella, C.A.; Tanovic, M.; Susarla, S.; Li, J.H.; Yang, H.; Ulloa, L.; Al-Abed, Y.; et al. Nicotinic acetylcholine receptor alpha7 subunit is an essential regulator of inflammation. Nature 2003, 421, 384-388. [CrossRef] [PubMed]

175. Marutle, A.; Gillberg, P.G.; Bergfors, A.; Yu, W.F.; Ni, R.; Nennesmo, I.; Voytenko, L.; Nordberg, A. H-3-Deprenyl and H-3-PIB autoradiography show different laminar distributions of astroglia and fibrillar beta-amyloid in Alzheimer brain. J. Neuroinflamm. 2013, 10, S491-S496. [CrossRef] 
176. Ikonomovic, M.D.; Wecker, L.; Abrahamson, E.E.; Wuu, J.; Counts, S.E.; Ginsberg, S.D.; Mufson, E.J.; Dekosky, S.T. Cortical alpha7 nicotinic acetylcholine receptor and beta-amyloid levels in early Alzheimer disease. Arch. Neurol. 2009, 66, 646-651. [CrossRef]

177. Yi, J.H.; Whitcomb, D.J.; Park, S.J.; Martinez-Perez, C.; Barbati, S.A.; Mitchell, S.J.; Cho, K. M1 muscarinic acetylcholine receptor dysfunction in moderate Alzheimer's disease pathology. Brain Commun. 2020, 2, fcaa058. [CrossRef]

178. Ni, R.; Marutle, A.; Nordberg, A. Modulation of $\alpha 7$ nicotinic acetylcholine receptor and fibrillar amyloid- $\beta$ interactions in Alzheimer's disease brain. J. Alzheimers Dis. 2013, 33, 841-851. [CrossRef]

179. Wang, H.-Y.; Stucky, A.; Liu, J.; Shen, C.; Trocme-Thibierge, C.; Morain, P. Dissociating beta-amyloid from alpha 7 nicotinic acetylcholine receptor by a novel therapeutic agent, S 24795, normalizes alpha 7 nicotinic acetylcholine and NMDA receptor function in Alzheimer's disease brain. J. Neurosci. 2009, 29, 10961-10973. [CrossRef]

180. Medeiros, R.; Castello, N.A.; Cheng, D.; Kitazawa, M.; Baglietto-Vargas, D.; Green, K.N.; Esbenshade, T.A.; Bitner, R.S.; Decker, M.W.; LaFerla, F.M. $\alpha 7$ Nicotinic receptor agonist enhances cognition in aged 3xTg-AD mice with robust plaques and tangles. Am. J. Pathol. 2014, 184, 520-529. [CrossRef]

181. George, A.A.; Vieira, J.M.; Xavier-Jackson, C.; Gee, M.T.; Cirrito, J.R.; Bimonte-Nelson, H.A.; Picciotto, M.R.; Lukas, R.J.; Whiteaker, P. Implications of Oligomeric Amyloid-Beta (oA $\beta(42))$ Signaling through $\alpha 7 \beta 2$-Nicotinic Acetylcholine Receptors (nAChRs) on Basal Forebrain Cholinergic Neuronal Intrinsic Excitability and Cognitive Decline. J. Neurosci. 2021, 41, 555-575. [CrossRef]

182. Ettrup, A.; Mikkelsen, J.D.; Lehel, S.; Madsen, J.; Nielsen, E.; Palner, M.; Timmermann, D.B.; Peters, D.; Knudsen, G.M. ${ }^{11}$ CNS14492 as a novel PET radioligand for imaging cerebral alpha7 nicotinic acetylcholine receptors: In vivo evaluation and drug occupancy measurements. J. Nucl. Med. 2011, 52, 1449-1456. [CrossRef] [PubMed]

183. Gao, Y.; Kellar, K.J.; Yasuda, R.P.; Tran, T.; Xiao, Y.; Dannals, R.F.; Horti, A.G. Derivatives of dibenzothiophene for positron emission tomography imaging of $\alpha 7$-nicotinic acetylcholine receptors. J. Med. Chem. 2013, 56, 7574-7589. [CrossRef] [PubMed]

184. Yamamoto, S.; Nishiyama, S.; Kawamata, M.; Ohba, H.; Wakuda, T.; Takei, N.; Tsukada, H.; Domino, E.F. Muscarinic Receptor Occupancy and Cognitive Impairment: A PET Study with $\left[{ }^{11} \mathrm{C}\right](+) 3-\mathrm{MPB}$ and Scopolamine in Conscious Monkeys. Neuropsychopharmacology 2011, 36, 1455-1465. [CrossRef] [PubMed]

185. Rowe, C.C.; Krishnadas, N.; Ackermann, U.; Doré, V.; Goh, R.Y.W.; Guzman, R.; Chong, L.; Bozinovski, S.; Mulligan, R.; Kanaan, R.; et al. PET Imaging of brain muscarinic receptors with ${ }^{18}$ F-Fluorobenzyl-Dexetimide: A first in human study. Psychiatry Res. Neuroimaging 2021, 316, 111354. [CrossRef]

186. Nabulsi, N.B.; Holden, D.; Zheng, M.Q.; Bois, F.; Lin, S.F.; Najafzadeh, S.; Gao, H.; Ropchan, J.; Lara-Jaime, T.; Labaree, D.; et al. Evaluation of ${ }^{11}$ C-LSN3172176 as a Novel PET Tracer for Imaging M(1) Muscarinic Acetylcholine Receptors in Nonhuman Primates. J. Nucl. Med. 2019, 60, 1147-1153. [CrossRef]

187. Tong, L.; Li, W.; Lo, M.M.-C.; Gao, X.; Wai, J.M.-C.; Rudd, M.; Tellers, D.; Joshi, A.; Zeng, Z.; Miller, P.; et al. Discovery of $\left[{ }^{11} \mathrm{C}\right] \mathrm{MK}-6884$ : A Positron Emission Tomography (PET) Imaging Agent for the Study of M4Muscarinic Receptor Positive Allosteric Modulators (PAMs) in Neurodegenerative Diseases. J. Med. Chem. 2020, 63, 2411-2425. [CrossRef] [PubMed]

188. Kadir, A.; Almkvist, O.; Wall, A.; Långström, B.; Nordberg, A. PET imaging of cortical ${ }^{11} \mathrm{C}$-nicotine binding correlates with the cognitive function of attention in Alzheimer's disease. Psychopharmacology 2006, 188, 509-520. [CrossRef]

189. Montagne, A.; Nikolakopoulou, A.M.; Huuskonen, M.T.; Sagare, A.P.; Lawson, E.J.; Lazic, D.; Rege, S.V.; Grond, A.; Zuniga, E.; Barnes, S.R.; et al. APOE4 accelerates advanced-stage vascular and neurodegenerative disorder in old Alzheimer's mice via cyclophilin A independently of amyloid- $\beta$. Nat. Aging 2021, 1, 506-520. [CrossRef]

190. Montagne, A.; Nation, D.A.; Sagare, A.P.; Barisano, G.; Sweeney, M.D.; Chakhoyan, A.; Pachicano, M.; Joe, E.; Nelson, A.R.; D'Orazio, L.M.; et al. APOE4 leads to blood-brain barrier dysfunction predicting cognitive decline. Nature 2020, 581, 71-76. [CrossRef]

191. Bien-Ly, N.; Boswell, C.A.; Jeet, S.; Beach, T.G.; Hoyte, K.; Luk, W.; Shihadeh, V.; Ulufatu, S.; Foreman, O.; Lu, Y.; et al. Lack of Widespread BBB Disruption in Alzheimer's Disease Models: Focus on Therapeutic Antibodies. Neuron 2015, 88, $289-297$. [CrossRef]

192. Merlini, M.; Meyer, E.P.; Ulmann-Schuler, A.; Nitsch, R.M. Vascular $\beta$-amyloid and early astrocyte alterations impair cerebrovascular function and cerebral metabolism in transgenic arcA $\beta$ mice. Acta Neuropathol. 2011, 122, 293-311. [CrossRef] [PubMed]

193. Erdő, F.; Denes, L.; de Lange, E. Age-associated physiological and pathological changes at the blood-brain barrier: A review. J. Cereb. Blood Flow Metab. 2017, 37, 4-24. [CrossRef] [PubMed]

194. Cirrito, J.R.; Deane, R.; Fagan, A.M.; Spinner, M.L.; Parsadanian, M.; Finn, M.B.; Jiang, H.; Prior, J.L.; Sagare, A.; Bales, K.R.; et al. P-glycoprotein deficiency at the blood-brain barrier increases amyloid-beta deposition in an Alzheimer disease mouse model. J. Clin. Investig. 2005, 115, 3285-3290. [CrossRef] [PubMed]

195. Mossel, P.; Garcia Varela, L.; Arif, W.M.; van der Weijden, C.W.J.; Boersma, H.H.; Willemsen, A.T.M.; Boellaard, R.; Elsinga, P.H.; Borra, R.J.H.; Colabufo, N.A.; et al. Evaluation of P-glycoprotein function at the blood-brain barrier using [ $\left.{ }^{18} \mathrm{~F}\right] \mathrm{MC} 225-\mathrm{PET}$. Eur. J. Nucl. Med. Mol. Imaging 2021, 1-2. [CrossRef]

196. Raaphorst, R.M.; Luurtsema, G.; Schuit, R.C.; Kooijman, E.J.M.; Elsinga, P.H.; Lammertsma, A.A.; Windhorst, A.D. Synthesis and Evaluation of New Fluorine-18 Labeled Verapamil Analogs To Investigate the Function of P-Glycoprotein in the Blood-Brain Barrier. ACS Chem. Neurosci. 2017, 8, 1925-1936. [CrossRef] 
197. García-Varela, L.; Arif, W.M.; Vállez García, D.; Kakiuchi, T.; Ohba, H.; Harada, N.; Tago, T.; Elsinga, P.H.; Tsukada, H.; Colabufo, N.A.; et al. Pharmacokinetic Modeling of $\left[{ }^{18} \mathrm{~F}\right] \mathrm{MC} 225$ for Quantification of the P-Glycoprotein Function at the Blood-Brain Barrier in Non-Human Primates with PET. Mol. Pharm. 2020, 17, 3477-3486. [CrossRef]

198. Savolainen, H.; Windhorst, A.D.; Elsinga, P.H.; Cantore, M.; Colabufo, N.A.; Willemsen, A.T.; Luurtsema, G. Evaluation of $\left[{ }^{18} \mathrm{~F}\right] \mathrm{MC} 225$ as a PET radiotracer for measuring P-glycoprotein function at the blood-brain barrier in rats: Kinetics, metabolism, and selectivity. J. Cereb. Blood Flow Metab. 2017, 37, 1286-1298. [CrossRef]

199. Schmidt, A.M.; Yan, S.D.; Yan, S.F.; Stern, D.M. The biology of the receptor for advanced glycation end products and its ligands. Biochim. Biophys. Acta 2000, 1498, 99-111. [CrossRef]

200. Yan, S.D.; Chen, X.; Fu, J.; Chen, M.; Zhu, H.; Roher, A.; Slattery, T.; Zhao, L.; Nagashima, M.; Morser, J.; et al. RAGE and amyloid-beta peptide neurotoxicity in Alzheimer's disease. Nature 1996, 382, 685-691. [CrossRef]

201. Kong, Y.; Hua, F.; Guan, Y.; Zhao, B. RAGE-specific probe ${ }^{18} \mathrm{~F}$-FPS-ZM1 may be a promising biomarker for early detection of Diabetes with Alzheimer's disease. J. Nucl. Med. 2016, 57, 1049.

202. Cary, B.P.; Brooks, A.F.; Fawaz, M.V.; Drake, L.R.; Desmond, T.J.; Sherman, P.; Quesada, C.A.; Scott, P.J. Synthesis and Evaluation of $\left[{ }^{18}\right.$ F]RAGER: A First Generation Small-Molecule PET Radioligand Targeting the Receptor for Advanced Glycation Endproducts. ACS Chem. Neurosci. 2016, 7, 391-398. [CrossRef]

203. Drake, L.R.; Brooks, A.F.; Stauff, J.; Sherman, P.S.; Arteaga, J.; Koeppe, R.A.; Reed, A.; Montavon, T.J.; Skaddan, M.B.; Scott, P.J.H. Strategies for PET imaging of the receptor for advanced glycation endproducts (RAGE). J. Pharm. Anal. 2020, 10, 452-465. [CrossRef]

204. Konopka, C.J.; Wozniak, M.; Hedhli, J.; Ploska, A.; Schwartz-Duval, A.; Siekierzycka, A.; Pan, D.; Munirathinam, G.; Dobrucki, I.T.; Kalinowski, L.; et al. Multimodal imaging of the receptor for advanced glycation end-products with molecularly targeted nanoparticles. Theranostics 2018, 8, 5012-5024. [CrossRef]

205. Kreisl, W.C.; Kim, M.J.; Coughlin, J.M.; Henter, I.D.; Owen, D.R.; Innis, R.B. PET imaging of neuroinflammation in neurological disorders. Lancet Neurol. 2020, 19, 940-950. [CrossRef]

206. Leng, F.; Edison, P. Neuroinflammation and microglial activation in Alzheimer disease: Where do we go from here? Nat. Rev. Neurol. 2021, 17, 157-172. [CrossRef] [PubMed]

207. Janssen, B.; Mach, R.H. Development of brain PET imaging agents: Strategies for imaging neuroinflammation in Alzheimer's disease. Prog. Mol. Biol. Transl. Sci. 2019, 165, 371-399. [CrossRef]

208. Van Camp, N.; Lavisse, S.; Roost, P.; Gubinelli, F.; Hillmer, A.; Boutin, H. TSPO imaging in animal models of brain diseases. Eur. J. Nucl. Med. Mol. Imaging 2021, 1-33. [CrossRef] [PubMed]

209. Bellaver, B.; Ferrari-Souza, J.P.; Uglione da Ros, L.; Carter, S.F.; Rodriguez-Vieitez, E.; Nordberg, A.; Pellerin, L.; Rosa-Neto, P.; Leffa, D.T.; Zimmer, E.R. Astrocyte Biomarkers in Alzheimer Disease: A Systematic Review and Meta-analysis. Neurology 2021, 96, e2944-e2955. [CrossRef]

210. Zhou, R.; Ji, B.; Kong, Y.; Qin, L.; Ren, W.; Guan, Y.; Ni, R. PET Imaging of Neuroinflammation in Alzheimer's Disease. Front. Immunol. 2021, 12, 3750. [CrossRef]

211. Pascoal, T.A.; Benedet, A.L.; Ashton, N.J.; Kang, M.S.; Therriault, J.; Chamoun, M.; Savard, M.; Lussier, F.Z.; Tissot, C.; Karikari, T.K.; et al. Microglial activation and tau propagate jointly across Braak stages. Nat. Med. 2021, 27, 1592-1599. [CrossRef]

212. Ising, C.; Venegas, C.; Zhang, S.; Scheiblich, H.; Schmidt, S.V.; Vieira-Saecker, A.; Schwartz, S.; Albasset, S.; McManus, R.M.; Tejera, D.; et al. NLRP3 inflammasome activation drives tau pathology. Nature 2019, 575, 669-673. [CrossRef] [PubMed]

213. Heneka, M.T.; Carson, M.J.; El Khoury, J.; Landreth, G.E.; Brosseron, F.; Feinstein, D.L.; Jacobs, A.H.; Wyss-Coray, T.; Vitorica, J.; Ransohoff, R.M.; et al. Neuroinflammation in Alzheimer's disease. Lancet Neurol. 2015, 14, 388-405. [CrossRef]

214. Huang, Y.; Happonen, K.E.; Burrola, P.G.; O'Connor, C.; Hah, N.; Huang, L.; Nimmerjahn, A.; Lemke, G. Microglia use TAM receptors to detect and engulf amyloid $\beta$ plaques. Nat. Immunol. 2021, 22, 586-594. [CrossRef] [PubMed]

215. Deczkowska, A.; Keren-Shaul, H.; Weiner, A.; Colonna, M.; Schwartz, M.; Amit, I. Disease-Associated Microglia: A Universal Immune Sensor of Neurodegeneration. Cell 2018, 173, 1073-1081. [CrossRef] [PubMed]

216. Keren-Shaul, H.; Spinrad, A.; Weiner, A.; Matcovitch-Natan, O.; Dvir-Szternfeld, R.; Ulland, T.K.; David, E.; Baruch, K.; LaraAstaiso, D.; Toth, B.; et al. A Unique Microglia Type Associated with Restricting Development of Alzheimer's Disease. Cell 2017, 169, 1276-1290.e17. [CrossRef]

217. Song, W.M.; Colonna, M. The identity and function of microglia in neurodegeneration. Nat. Immunol. 2018, 19, 1048-1058. [CrossRef]

218. Venneti, S.; Lopresti, B.J.; Wang, G.; Hamilton, R.L.; Mathis, C.A.; Klunk, W.E.; Apte, U.M.; Wiley, C.A. PK11195 labels activated microglia in Alzheimer's disease and in vivo in a mouse model using PET. Neurobiol. Aging 2009, 30, 1217-1226. [CrossRef]

219. Mirzaei, N.; Tang, S.P.; Ashworth, S.; Coello, C.; Plisson, C.; Passchier, J.; Selvaraj, V.; Tyacke, R.J.; Nutt, D.J.; Sastre, M. In vivo imaging of microglial activation by positron emission tomography with [ ${ }^{11}$ C]PBR28 in the 5XFAD model of Alzheimer's disease. Glia 2016, 64, 993-1006. [CrossRef]

220. Ikawa, M.; Lohith, T.G.; Shrestha, S.; Telu, S.; Zoghbi, S.S.; Castellano, S.; Taliani, S.; Da Settimo, F.; Fujita, M.; Pike, V.W.; et al. ${ }^{11}$ C-ER176, a Radioligand for 18-kDa Translocator Protein, Has Adequate Sensitivity to Robustly Image All Three Affinity Genotypes in Human Brain. J. Nucl. Med. 2017, 58, 320-325. [CrossRef] 
221. Wright, A.L.; Zinn, R.; Hohensinn, B.; Konen, L.M.; Beynon, S.B.; Tan, R.P.; Clark, I.A.; Abdipranoto, A.; Vissel, B. Neuroinflammation and Neuronal Loss Precede A $\beta$ Plaque Deposition in the hAPP-J20 Mouse Model of Alzheimer's Disease. PLoS ONE 2013, 8, e59586. [CrossRef]

222. López-Picón, F.R.; Snellman, A.; Eskola, O.; Helin, S.; Solin, O.; Haaparanta-Solin, M.; Rinne, J.O. Neuroinflammation Appears Early on PET Imaging and Then Plateaus in a Mouse Model of Alzheimer Disease. J. Nucl. Med. 2018, 59, 509. [CrossRef]

223. Brendel, M.; Kleinberger, G.; Probst, F.; Jaworska, A.; Overhoff, F.; Blume, T.; Albert, N.L.; Carlsen, J.; Lindner, S.; Gildehaus, F.J.; et al. Increase of TREM2 during Aging of an Alzheimer's Disease Mouse Model Is Paralleled by Microglial Activation and Amyloidosis. Front. Aging Neurosci. 2017, 9, 8. [CrossRef]

224. Focke, C.; Blume, T.; Zott, B.; Shi, Y.; Deussing, M.; Peters, F.; Schmidt, C.; Kleinberger, G.; Lindner, S.; Gildehaus, F.J.; et al. Early and Longitudinal Microglial Activation but Not Amyloid Accumulation Predicts Cognitive Outcome in PS2APP Mice. J. Nucl. Med. 2019, 60, 548-554. [CrossRef] [PubMed]

225. Chaney, A.; Cropper, H.C.; Johnson, E.M.; Lechtenberg, K.J.; Peterson, T.C.; Stevens, M.Y.; Buckwalter, M.S.; James, M.L. ${ }^{11}$ C-DPA713 Versus ${ }^{18}$ F-GE-180: A Preclinical Comparison of Translocator Protein 18 kDa PET Tracers to Visualize Acute and Chronic Neuroinflammation in a Mouse Model of Ischemic Stroke. J. Nucl. Med. 2019, 60, 122-128. [CrossRef]

226. Ji, B.; Ono, M.; Yamasaki, T.; Fujinaga, M.; Zhang, M.R.; Seki, C.; Aoki, I.; Kito, S.; Sawada, M.; Suhara, T.; et al. Detection of Alzheimer's disease-related neuroinflammation by a PET ligand selective for glial versus vascular translocator protein. J. Cereb. Blood Flow Metab. 2021, 271678x21992457. [CrossRef] [PubMed]

227. Beaino, W.; Janssen, B.; Vugts, D.J.; de Vries, H.E.; Windhorst, A.D. Toward PET imaging of the dynamic phenotypes of microglia. Clin. Exp. Immunol. 2021, 206, 282-300. [CrossRef] [PubMed]

228. Ni, R.; Müller Herde, A.; Haider, A.; Keller, C.; Louloudis, G.; Vaas, M.; Schibli, R.; Ametamey, S.M.; Klohs, J.; Mu, L. In vivo Imaging of Cannabinoid Type 2 Receptors: Functional and Structural Alterations in Mouse Model of Cerebral Ischemia by PET and MRI. bioRxiv 2021. [CrossRef]

229. Hagens, M.H.J.; Golla, S.S.V.; Janssen, B.; Vugts, D.J.; Beaino, W.; Windhorst, A.D.; O’Brien-Brown, J.; Kassiou, M.; Schuit, R.C.; Schwarte, L.A.; et al. The P2X7 receptor tracer [ $\left.{ }^{11} \mathrm{C}\right] \mathrm{SMW} 139$ as an in vivo marker of neuroinflammation in multiple sclerosis: A first-in man study. Eur. J. Nucl. Med. Mol. Imaging 2020, 47, 379-389. [CrossRef]

230. Janssen, B.; Vugts, D.J.; Wilkinson, S.M.; Ory, D.; Chalon, S.; Hoozemans, J.J.M.; Schuit, R.C.; Beaino, W.; Kooijman, E.J.M.; van den Hoek, J.; et al. Identification of the allosteric P2X7 receptor antagonist $\left[{ }^{11} \mathrm{C}\right]$ SMW139 as a PET tracer of microglial activation. Sci. Rep. 2018, 8, 6580. [CrossRef]

231. Maeda, J.; Minamihisamatsu, T.; Shimojo, M.; Zhou, X.; Ono, M.; Matsuba, Y.; Ji, B.; Ishii, H.; Ogawa, M.; Akatsu, H.; et al. Distinct microglial response against Alzheimer's amyloid and tau pathologies characterized by P2Y12 receptor. Brain Commun. 2021, 3, fcab011. [CrossRef]

232. Horti, A.G.; Naik, R.; Foss, C.A.; Minn, I.; Misheneva, V.; Du, Y.; Wang, Y.; Mathews, W.B.; Wu, Y.; Hall, A.; et al. PET imaging of microglia by targeting macrophage colony-stimulating factor 1 receptor (CSF1R). Proc. Natl. Acad. Sci. USA 2019, 116, 1686-1691. [CrossRef] [PubMed]

233. Zhou, X.; Ji, B.; Seki, C.; Nagai, Y.; Minamimoto, T.; Fujinaga, M.; Zhang, M.R.; Saito, T.; Saido, T.C.; Suhara, T.; et al. PET imaging of colony-stimulating factor 1 receptor: A head-to-head comparison of a novel radioligand, ${ }^{11} \mathrm{C}-\mathrm{GW} 2580$, and ${ }^{11} \mathrm{C}-\mathrm{CPPC}$, in mouse models of acute and chronic neuroinflammation and a rhesus monkey. J. Cereb. Blood Flow Metab. 2021, $271678 \times 211004146$. [CrossRef] [PubMed]

234. Shukuri, M.; Mawatari, A.; Ohno, M.; Suzuki, M.; Doi, H.; Watanabe, Y.; Onoe, H. Detection of Cyclooxygenase-1 in Activated Microglia During Amyloid Plaque Progression: PET Studies in Alzheimer's Disease Model Mice. J. Nucl. Med. 2016, 57, 291-296. [CrossRef] [PubMed]

235. Meier, S.R.; Sehlin, D.; Hultqvist, G.; Syvänen, S. Pinpointing Brain TREM2 Levels in Two Mouse Models of Alzheimer's Disease. Mol. Imaging Biol. 2021, 1-11. [CrossRef]

236. Thomsen, M.B.; Jacobsen, J.; Lillethorup, T.P.; Schacht, A.C.; Simonsen, M.; Romero-Ramos, M.; Brooks, D.J.; Landau, A.M. In vivo imaging of synaptic SV2A protein density in healthy and striatal-lesioned rats with [ $\left.{ }^{11} \mathrm{C}\right] \mathrm{UCB}-\mathrm{J}$ PET. J. Cereb. Blood Flow Metab. 2021, 41, 819-830. [CrossRef] [PubMed]

237. Parbo, P.; Ismail, R.; Hansen, K.V.; Amidi, A.; Mårup, F.H.; Gottrup, H.; Brændgaard, H.; Eriksson, B.O.; Eskildsen, S.F.; Lund, T.E.; et al. Brain inflammation accompanies amyloid in the majority of mild cognitive impairment cases due to Alzheimer's disease. Brain 2017, 140, 2002-2011. [CrossRef] [PubMed]

238. Hou, C.; Hsieh, C.-J.; Li, S.; Lee, H.; Graham, T.J.; Xu, K.; Weng, C.-C.; Doot, R.K.; Chu, W.; Chakraborty, S.K.; et al. Development of a Positron Emission Tomography Radiotracer for Imaging Elevated Levels of Superoxide in Neuroinflammation. ACS Chem. Neurosci. 2018, 9, 578-586. [CrossRef]

239. Schützmann, M.P.; Hasecke, F.; Bachmann, S.; Zielinski, M.; Hänsch, S.; Schröder, G.F.; Zempel, H.; Hoyer, W. Endo-lysosomal $\mathrm{A} \beta$ concentration and $\mathrm{pH}$ trigger formation of $\mathrm{A} \beta$ oligomers that potently induce Tau missorting. Nat. Commun. 2021, 12,4634 . [CrossRef]

240. Kumar, J.S.D.; Solingapuram Sai, K.K.; Prabhakaran, J.; Oufkir, H.R.; Ramanathan, G.; Whitlow, C.T.; Dileep, H.; Mintz, A.; Mann, J.J. Radiosynthesis and in Vivo Evaluation of $\left[{ }^{11} \mathrm{C}\right] \mathrm{MPC}-6827$, the First Brain Penetrant Microtubule PET Ligand. J. Med. Chem. 2018, 61, 2118-2123. [CrossRef] 
241. Solingapuram Sai, K.K.; Prabhakaran, J.; Ramanathan, G.; Rideout, S.; Whitlow, C.; Mintz, A.; Mann, J.J.; Kumar, J.S.D. Radiosynthesis and Evaluation of $\left[{ }^{11} \mathrm{C}\right] \mathrm{HD}-800$, a High Affinity Brain Penetrant PET Tracer for Imaging Microtubules. ACS Med. Chem. Lett. 2018, 9, 452-456. [CrossRef]

242. Baum, E.; Cai, Z.; Bois, F.; Holden, D.; Lin, S.F.; Lara-Jaime, T.; Kapinos, M.; Chen, Y.; Deuther-Conrad, W.; Fischer, S.; et al. PET Imaging Evaluation of Four $\sigma(1)$ Radiotracers in Nonhuman Primates. J. Nucl. Med. 2017, 58, 982-988. [CrossRef] [PubMed]

243. Lepelletier, F.-X.; Vandesquille, M.; Asselin, M.-C.; Prenant, C.; Robinson, A.C.; Mann, D.M.A.; Green, M.; Barnett, E.; Banister, S.D.; Mottinelli, M.; et al. Evaluation of ${ }^{18} \mathrm{~F}-\mathrm{IAM} 6067$ as a sigma-1 receptor PET tracer for neurodegeneration in vivo in rodents and in human tissue. Theranostics 2020, 10, 7938-7955. [CrossRef] [PubMed]

244. Lan, Y.; Bai, P.; Chen, Z.; Neelamegam, R.; Placzek, M.S.; Wang, H.; Fiedler, S.A.; Yang, J.; Yuan, G.; Qu, X.; et al. Novel radioligands for imaging sigma-1 receptor in brain using positron emission tomography (PET). Acta Pharm. Sin. B 2019, 9 , 1204-1215. [CrossRef] [PubMed]

245. Knight, A.C.; Varlow, C.; Tong, J.; Vasdev, N. In Vitro and In Vivo Evaluation of GSK-3 Radioligands in Alzheimer's Disease: Preliminary Evidence of Sex Differences. ACS Pharmacol. Transl. Sci. 2021, 4, 1287-1294. [CrossRef]

246. Escartin, C.; Galea, E.; Lakatos, A.; O'Callaghan, J.P.; Petzold, G.C.; Serrano-Pozo, A.; Steinhäuser, C.; Volterra, A.; Carmignoto, G.; Agarwal, A.; et al. Reactive astrocyte nomenclature, definitions, and future directions. Nat. Neurosci. 2021, 24, 312-325. [CrossRef]

247. Joshi, A.U.; Minhas, P.S.; Liddelow, S.A.; Haileselassie, B.; Andreasson, K.I.; Dorn, G.W., 2nd; Mochly-Rosen, D. Fragmented mitochondria released from microglia trigger A1 astrocytic response and propagate inflammatory neurodegeneration. Nat. Neurosci. 2019, 22, 1635-1648. [CrossRef]

248. Castellani, G.; Schwartz, M. Immunological Features of Non-neuronal Brain Cells: Implications for Alzheimer's Disease Immunotherapy. Trends Immunol. 2020, 41, 794-804. [CrossRef]

249. McAlpine, C.S.; Park, J.; Griciuc, A.; Kim, E.; Choi, S.H.; Iwamoto, Y.; Kiss, M.G.; Christie, K.A.; Vinegoni, C.; Poller, W.C.; et al. Astrocytic interleukin-3 programs microglia and limits Alzheimer's disease. Nature 2021, 595, 701-706. [CrossRef]

250. Damisah, E.C.; Hill, R.A.; Rai, A.; Chen, F.; Rothlin, C.V.; Ghosh, S.; Grutzendler, J. Astrocytes and microglia play orchestrated roles and respect phagocytic territories during neuronal corpse removal in vivo. Sci. Adv. 2020, 6, eaba3239. [CrossRef]

251. Habib, N.; McCabe, C.; Medina, S.; Varshavsky, M.; Kitsberg, D.; Dvir-Szternfeld, R.; Green, G.; Dionne, D.; Nguyen, L.; Marshall, J.L.; et al. Disease-associated astrocytes in Alzheimer's disease and aging. Nat. Neurosci. 2020, 23, 701-706. [CrossRef]

252. Olsen, M.; Aguilar, X.; Sehlin, D.; Fang, X.T.; Antoni, G.; Erlandsson, A.; Syvänen, S. Astroglial Responses to Amyloid-Beta Progression in a Mouse Model of Alzheimer's Disease. Mol. Imaging Biol. 2018, 20, 605-614. [CrossRef]

253. Harada, R.; Hayakawa, Y.; Ezura, M.; Lerdsirisuk, P.; Du, Y.; Ishikawa, Y.; Iwata, R.; Shidahara, M.; Ishiki, A.; Kikuchi, A.; et al. ${ }^{18}$ F-SMBT-1: A Selective and Reversible PET Tracer for Monoamine Oxidase-B Imaging. J. Nucl. Med. 2021, 62, 253-258. [CrossRef] [PubMed]

254. Alzghool, O.M.; Rokka, J.; López-Picón, F.R.; Snellman, A.; Helin, J.S.; Okamura, N.; Solin, O.; Rinne, J.O.; Haaparanta-Solin, M. (S)- $\left[{ }^{18} \mathrm{~F}\right]$ THK5117 brain uptake is associated with $\mathrm{A} \beta$ plaques and MAO-B enzyme in a mouse model of Alzheimer's disease. Neuropharmacology 2021, 196, 108676. [CrossRef] [PubMed]

255. Dukić-Stefanović, S.; Hang Lai, T.; Toussaint, M.; Clauß, O.; Jevtić, I.I.; Penjišević, J.Z.; Andrić, D.; Ludwig, F.A.; Gündel, D.; Deuther-Conrad, W.; et al. In vitro and in vivo evaluation of fluorinated indanone derivatives as potential positron emission tomography agents for the imaging of monoamine oxidase B in the brain. Bioorg. Med. Chem. Lett. 2021, 48, 128254. [CrossRef] [PubMed]

256. Kumar, A.; Koistinen, N.A.; Malarte, M.-L.; Nennesmo, I.; Ingelsson, M.; Ghetti, B.; Lemoine, L.; Nordberg, A. Astroglial tracer BU99008 detects multiple binding sites in Alzheimer's disease brain. Mol. Psychiatry 2021, 1-15. [CrossRef] [PubMed]

257. Livingston, N.R.; Calsolaro, V.; Hinz, R.; Nowell, J.; Raza, S.; Gentleman, S.; Tyacke, R.J.; Myers, J.; Venkataraman, A.V.; Perneczky, R.; et al. Relationship between astrocyte reactivity, using novel ${ }^{11} \mathrm{C}$-BU99008 PET, and glucose metabolism, grey matter volume and amyloid load in cognitively impaired individuals. medRxiv 2021. [CrossRef]

258. Calsolaro, V.; Matthews, P.M.; Donat, C.K.; Livingston, N.R.; Femminella, G.D.; Guedes, S.S.; Myers, J.; Fan, Z.; Tyacke, R.J.; Venkataraman, A.V.; et al. Astrocyte reactivity with late-onset cognitive impairment assessed in vivo using ${ }^{11} \mathrm{C}-\mathrm{BU} 99008 \mathrm{PET}$ and its relationship with amyloid load. Mol. Psychiatry 2021, 1-8. [CrossRef]

259. Ni, R.; Ji, B.; Ono, M.; Sahara, N.; Zhang, M.R.; Aoki, I.; Nordberg, A.; Suhara, T.; Higuchi, M. Comparative In Vitro and In Vivo Quantifications of Pathologic Tau Deposits and Their Association with Neurodegeneration in Tauopathy Mouse Models. J. Nucl. Med. 2018, 59, 960-966. [CrossRef]

260. Ishikawa, A.; Tokunaga, M.; Maeda, J.; Minamihisamatsu, T.; Shimojo, M.; Takuwa, H.; Ono, M.; Ni, R.; Hirano, S.; Kuwabara, S.; et al. In Vivo Visualization of Tau Accumulation, Microglial Activation, and Brain Atrophy in a Mouse Model of Tauopathy rTg4510. J. Alzheimers Dis. 2018, 61, 1037-1052. [CrossRef]

261. Ni, R.; Rudin, M.; Klohs, J. Cortical hypoperfusion and reduced cerebral metabolic rate of oxygen in the arcA $\beta$ mouse model of Alzheimer's disease. Photoacoustics 2018, 10, 38-47. [CrossRef]

262. Colom-Cadena, M.; Spires-Jones, T.; Zetterberg, H.; Blennow, K.; Caggiano, A.; DeKosky, S.T.; Fillit, H.; Harrison, J.E.; Schneider, L.S.; Scheltens, P.; et al. The clinical promise of biomarkers of synapse damage or loss in Alzheimer's disease. Alzheimers Res. Ther. 2020, 12, 21. [CrossRef]

263. Neuner, S.M.; Heuer, S.E.; Huentelman, M.J.; O'Connell, K.M.S.; Kaczorowski, C.C. Harnessing Genetic Complexity to Enhance Translatability of Alzheimer's Disease Mouse Models: A Path toward Precision Medicine. Neuron 2019, 101, 399-411.e5. [CrossRef] 
264. Hodge, R.D.; Bakken, T.E.; Miller, J.A.; Smith, K.A.; Barkan, E.R.; Graybuck, L.T.; Close, J.L.; Long, B.; Johansen, N.; Penn, O.; et al. Conserved cell types with divergent features in human versus mouse cortex. Nature 2019, 573, 61-68. [CrossRef]

265. Rosen, R.F.; Tomidokoro, Y.; Farberg, A.S.; Dooyema, J.; Ciliax, B.; Preuss, T.M.; Neubert, T.A.; Ghiso, J.A.; LeVine, H., 3rd; Walker, L.C. Comparative pathobiology of $\beta$-amyloid and the unique susceptibility of humans to Alzheimer's disease. Neurobiol. Aging 2016, 44, 185-196. [CrossRef] [PubMed]

266. Vitek, M.P.; Araujo, J.A.; Fossel, M.; Greenberg, B.D.; Howell, G.R.; Rizzo, S.J.S.; Seyfried, N.T.; Tenner, A.J.; Territo, P.R.; Windisch, M.; et al. Translational animal models for Alzheimer's disease: An Alzheimer's Association Business Consortium Think Tank. Alzheimer's Dement. 2020, 6, e12114. [CrossRef] [PubMed]

267. Oblak, A.L.; Forner, S.; Territo, P.R.; Sasner, M.; Carter, G.W.; Howell, G.R.; Sukoff-Rizzo, S.J.; Logsdon, B.A.; Mangravite, L.M.; Mortazavi, A.; et al. Model organism development and evaluation for late-onset Alzheimer's disease: MODEL-AD. Alzheimers Dement. 2020, 6, e12110. [CrossRef] [PubMed]

268. Preuss, C.; Pandey, R.; Piazza, E.; Fine, A.; Uyar, A.; Perumal, T.; Garceau, D.; Kotredes, K.P.; Williams, H.; Mangravite, L.M.; et al. A novel systems biology approach to evaluate mouse models of late-onset Alzheimer's disease. Mol. Neurodegener. 2020, 15, 67. [CrossRef] 